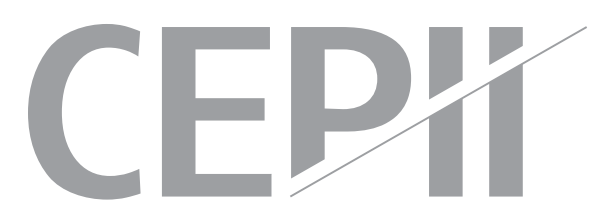

\title{
Firms' Exports, Volatility and Skills: Evidence from France
}

Maria Bas, Pamela Bombarda, Sébastien Jean \& Gianluca Orefice

\section{Highlights}

- This paper analyzes how firms' exporting activity affect the volatility of skilled and unskilled labor demand.

- We find that firms with higher export intensity exhibit a lower volatility of skilled labor demand relative to the volatility of unskilled labor demand.

- This effect is driven by the extensive margin component (i.e. number of export destination) and it is bigger in magnitude for extra-EU destinations. 


\section{Abstract}

Inequalities between workers of different skills have been growing in the era of globalization. Firms' internationalization mode has an impact on job stability. Exporting firms are not only exposed to different foreign shocks, they also pay skill-intensive fixed costs to serve foreign markets. This implies that, for larger exporters, the labor demand for skilled workers is expected to be less volatile than for unskilled workers. In this paper we study the relationship between firms' export activity and job stability across employment skills. Relying on detailed firm-level data from France for the period 1996-2007, we show that firms with higher export intensity exhibit a lower volatility of skilled labor demand relative to the volatility of unskilled labor demand. Our identification strategy is based on an instrumental variable approach to provide evidence on the causal effect of the export performance of the firm on the volatility of employment of different skills. Our findings suggest that exporting increases the stability of skilled jobs, but feeds the precariousness of unskilled ones.

\section{Keywords}

Exports, Employment Volatility, Skiller Labor, Firm-level Data.

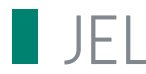

F1, F16, L25, L60.

\section{Working Paper}

\section{CEPI}

CEPII (Centre d'Etudes Prospectives et d'Informations Internationales) is a French institute dedicated to producing independent, policyoriented economic research helpful to understand the international economic environment and challenges in the areas of trade policy, competitiveness, macroeconomics, international finance and growth.
CEPII Working Paper

Contributing to research in international economics

C CEPII, PARIS, 2018

All rights reserved. Opinions expressed in this publication are those of the author(s) alone.

$\begin{array}{ll}\text { Editorial Director: } & \text { CEPII } \\ \text { Sébastien Jean } & \text { 20, avenue de Ségur } \\ & \text { TSA 10726 } \\ \text { Production: } & 75334 \text { Paris Cedex } 07 \\ \text { Laure Boivin } & +33153685500 \\ & \text { www.cepii.fr } \\ \text { No ISSN: } 1293-2574 & \text { Press contact: presse@ }\end{array}$




\title{
Firms' Exports, Volatility and Skills: Evidence from France ${ }^{1}$
}

\author{
Maria Bas (University of Paris 1 Pantheon-Sorbonne)* \\ Pamela Bombarda (University of Cergy, THEMA) ${ }^{\dagger}$ \\ Sébastien Jean (CEPII and INRA) $)^{\ddagger}$
}

Gianluca Orefice (CEPII) ${ }^{\S}$

\section{Introduction}

During the past decades, globalization has been often claimed to enhance inequalities between skilled and less skilled workers in the labor market. Firms engaged in international trade tend to be more skilled intensive and pay higher wages (Bernard et al., 2007), with important consequences on the labor market of the country, such as job instability and wage inequality. In many developed countries, job opportunities for unskilled workers declined over the last globalization wave, while internationalization fueled new job opportunities for highskilled workers. At the same time, the skilled premium grew either because wages of skilled workers rose more rapidly than those of unskilled workers, or simply because the wages of unskilled workers collapsed. These facts concerning the labor markets of many developed and developing countries may be related to globalization and in particular to export dynamics of firms. Several theoretical models show that firms' export activity has an unequal effect on skilled and unskilled labor demand and wages (examples include Burstein and Vogel, 2017;

\footnotetext{
${ }^{1}$ We thank participants of the CEPII seminar, International Economics and Labor Markets seminar at University of Paris 1, The Royal Economic Society meeting 2017, the Trade and Labor Market workshop at University of Milan 2017, DEGIT conference 2017, University of Le Mans, University of Cergy Pontoise, University of Munich, OECD applied economic. We have benefited from discussions with Andrea Ariu, Lionel Fontagné, Thierry Mayer, Hillel Rapoport, Ariell Reshef, Farid Toubal and Maurizio Zanardi.

*maria.bas@univ-paris1.fr

†pamela.bombarda@u-cergy.fr

$\ddagger$ sebastien.jean@cepii.fr

$\S$ gianluca.orefice@cepii.fr
} 
Harrigan and Reshef, 2015; Brambilla et al., 2012; Verhoogen, 2008; Yeaple, 2005). In addition, recent micro-econometric evidence highlights that exporting firms facing idiosyncratic shocks in their destination markets, exhibit higher domestic sales volatility (Berman et al., 2015, Vannoorenberghe, 2012) and total employment growth volatility (Kurz and Senses, 2016). However, this leaves unaddressed an important question regarding the labor market consequences of globalization, namely whether it may also affect differently the job stability (i.e. employment volatility) of skilled and unskilled workers.

The aim of this paper is to fill this gap by studying the causal impact of firms' exporting activity on employment volatility across skills. This is a key research question because firms' export capacity might have an unequal effect on the stability of jobs (i.e. employment volatility) of workers with different qualifications. Our findings show that the global engagement of the firm triggers inequalities between skilled and unskilled workers in the form of job stability. Firms more engaged and diversified in export markets are associated with greater precariousness of unskilled relatively to skilled jobs. We can think of different mechanisms rationalizing the heterogeneous effect of exports on the employment volatility of workers of different skills. For instance, fixed costs of production to reach foreign markets can be intensive in skilled labor. This implies that the amount of skilled workers would react by a lower extent to variation in export sales. Related to this channel, entry and exit dynamics into foreign destinations can also explain the heterogeneous reply of firm's skilled and unskilled labor demands. Finally, introducing search and matching frictions in presence of heterogeneous workers will also deliver different labor demand reactions to common foreign shocks. We dedicate section 3 to a detailed discussion of the channels through which firm's exports may have an unequal effect on the job stability between skilled and unskilled workers.

Our empirical analysis is developed in two steps. We first present some facts on employment volatility in France over the period 1996 - 2007. We show that the volatility of unskilled labor is greater for firms with higher export capacity (measured as total exports or as number of destinations served). In contrast, the volatility of skilled labor is negatively correlated with export performance. Additionally, we find a positive link between skill intensity and the number 
of destinations reached, supporting the intuition that export activity is skilled-intensive. This fact seems consistent with a theoretical framework in which exporting to a foreign market implies a skill-intensive fixed cost. ${ }^{2}$ In the Appendix we present a simple theoretical framework that rationalizes the skill intensive fixed costs mechanism. We show that, for a given firm's size, higher exports imply a smaller ratio between the volatility of skilled labor demand and the volatility of unskilled labor demand. In what follows, we refer to this ratio as the relative volatility of skilled labor demand.

In the second step, we use employer-employee data from the Déclaration Annuelle des Données Sociales (DADS) and French trade flows from the French Customs Data to assess the causal relationship between export and employment volatility of different skills. Our baseline identification strategy relies on the variation of total exports and employment volatility across firms within a sector, conditional on firms' size and firm-specific foreign supply shocks. The average effect of total exports on the relative volatility of skilled labor demand is negative. This result confirms that larger volumes of exports increase the volatility of low-skilled workers relative to high-skilled workers, i.e. inequality in job stability. We also test the effect exports on skilled and unskilled workers separately. We show that the negative effect of exports on the relative volatility of skilled labor demand is the result of a negative (positive) effect of exports on the volatility of skilled (unskilled) workers.

We also address possible endogeneity concerns that may arise in this context. Firms' export sales and employment demand may be determined by the same (unobserved) firm's supply and demand factors. In particular, skill-biased technological shocks may affect both export sales and the volatility of a specific type of worker. ${ }^{3}$ We deal with this potential issue using instrumental variables estimation based on exogenous demand shocks faced by firms in their export markets. More specifically, we use sectoral real exchange rates and initial level of firms' exports to capture exogenous shocks faced by each firm in destination markets.

\footnotetext{
${ }^{2}$ Artopoulos et al. (2011), and Cavusgil and Zou (1994) highlight that a large part of fixed export costs are composed of logistical, coordination and distributional operations, which are usually more skill-intensive.

${ }^{3}$ In our empirical framework, technological shocks (or other unobserved factors) affecting skilled and unskilled workers in the same way are controlled by taking the ratio of volatility between skilled and unskilled workers.
} 
Then, we explore the possible channels of transmission. To do so, we break down total exports into their intensive and extensive margin components, and show that this latter plays a dominant role. This finding suggests that the diversification of export markets (increasing the number of destinations reached) is the key export performance that affects negatively the relative volatility of skilled labor demand. Another related mechanism driving our findings is that employment volatility can be associated with entry and exit into the destination market. We test for this channel by calculating the export sales on continuous destinations served by the firm, and sales in markets where the firm exports intermittently during the period (i.e. churning destinations). Our results show that firms' exports to churning destinations affect the volatility of employment to a larger extent than exports to continuous destinations. This suggests that the entry/exit dynamic of firms to/from foreign markets plays an important role on the relative volatility of employment. We also present a test for the heterogeneous effect of firm export sales on the volatility of employment of different skills depending on the initial size of the firm. The rationale for this exercise is that firms exporting to more destinations tend to be larger. Our results confirm that the effect of exports on the employment volatility of different skills is driven by big firms.

Lastly, we present several robustness tests. We first control for alternative explanations of our results. One possible explanation is related to the presence of multinational firms that can manage employment across plants in different countries. Our results hold when we exclude multinational firms from the sample. Another alternative explanation is related to the fact that more productive firms are more skill-intensive and export more (and to more destinations). The different level of productivity across exporting firms might explain the heterogeneous effect of exports on the volatility of skilled and unskilled labor. When we explicitly control for the productivity of the firm, our results are robust and stable, proving that the effect of exports on employment volatility is not driven by differences in productivity across firms. Second, we rely on the entrance of China into the WTO in 2001 as an exogenous trade shock increasing export opportunities for French firms to test if our findings are affected by this shock. We show that our main results still hold. Third, our findings are 
also robust and stable when relying on alternative dependent variables, such as the volatility of hours worked instead of employment, the coefficient of variation instead of the standard deviation as proxy for volatility, and when we change the definition of skills using production versus non-production workers.

This paper relates to several strands of research. It contributes to the micro-econometric literature that focuses on the effects of international trade on employment. Using trade and transactions data for the U.S. manufacturing sector, Kurz and Senses (2016) find that the firm-level labor demand volatility is larger for exporting than for non-exporting firms, and it is decreasing with the export sales of the firm. In our paper, we study the heterogeneous effect of firm exports across employment skills. We use employer-employee and custom data for France, to analyze how firms' exporting activity affects the volatility of skilled and unskilled labor demand. We empirically investigate one of the possible explanations (fixed costs channel) behind the higher (lower) employment volatility of unskilled (skilled) workers. Finally, we address possible endogeneity concerns that may arise in this context, and use instrumental variables estimation to establish the link between foreign demand shocks and employment volatility. Our results emphasize that firms' export sales are associated with greater instability of unskilled labor jobs relative to skilled ones. These findings reinforce and enrich the evidence of the previous literature studying the effect of international trade on inequalities in labor markets across employment skills (e.g. Burstein and Vogel, 2017, and Biscourp and Kramarz, 2007 among others).

Our paper also contributes to the growing literature on the relationship between different measures of firm's volatility and trade. An extensive literature studies the determinants of volatility using industry-level data. Krebs et al. (2010) propose a two steps estimation where they link the volatility of income at the sectoral level to trade policy. Kalemli-Ozcan et al. (2014) document a positive relationship between foreign direct ownership of firms and firm- and region level output volatility. Other papers focus on macroeconomic volatility and openness. For example, di Giovanni and Levchenko (2009) show that trade raises aggregate volatility by making aggregate national output more dependent on idiosyncratic shocks. Cu- 
nat and Melitz (2012) study the relationship between volatility, labor market flexibility, and openness, and show that countries with relatively flexible labor markets concentrate their exports relatively more intensively in sectors with higher volatility. Caselli et al. (2015) point out the importance of geographic diversification to mitigate country-specific shocks. Other recent works assess the importance of the firm-specific components to micro and macro fluctuations. Vannoorenberghe (2012) shows that the share of exports in the total sales of a firm has a positive and substantial impact on the volatility of its sales; while di Giovanni et al. (2014) study the role of individual firms in generating aggregate fluctuations. The research on aggregate fluctuations and its microeconomic sources is growing (Kramarz et al., 2017, di Giovanni et al., 2018).

The rest of the paper is organized as follows. Section 2 highlights some key facts that will be investigated in the subsequent empirical analysis. Section 3 presents the theoretical motivation. Section 4 describes the data. Section 5 lays out the estimation strategy and discusses potential endogeneity concerns. Section 6 presents the baseline results. Section 7 explores the channels of transmission and Section 8 proposes robustness checks. Section 9 concludes.

\section{A First Glance at the Data}

This section presents descriptive evidence on the relationship between export sales and the volatility of employment of different skills. Relying on firm-level data from France for the period 1996-2007, we derive two main empirical facts. ${ }^{4}$

First, we investigate the correlation between exports and the volatility of skilled and unskilled workers. Following Kurz and Senses (2016), employment volatility is measured as the standard deviation of the residual component of an employment growth rate estimation over the period 1996-2007 (see section 5 for a detailed description of how we computed employment volatility). Since we do not have information on the education level of workers, we classify skilled versus unskilled workers using their occupation's wage. More specifically, we consider

\footnotetext{
${ }^{4} \mathrm{~A}$ detailed description of the data used in this manuscript is reported in section 4.
} 
skilled those workers employed in occupations whose initial (average) wage is above the median wage in the sample, and unskilled the others. ${ }^{5}$ To characterize firms' export exposure, we rank firms by two alternative measures, export intensity (as total exports of the firm) and number of destinations served. The average firm-level employment volatility (conditioned on size) is then compared across deciles for each of these two rankings. Whatever the measure, the volatility of firms' demand for unskilled labor appears to be clearly larger for firms with larger export exposure (Figures 1a and 1b). Strikingly, the opposite is true for the volatility of skilled labor demand, especially for large exporters (Figures $1 \mathrm{c}$ and 1d). The clearcut contrast between skill categories is suggestive of opposite influences of exporting upon labor demand volatility by skill.

Second, we consider the correlation between firms' export exposure and skilled intensity. We classify firms into different deciles of export sales and number of destinations served by each firm. ${ }^{6}$ We plot these measures of export exposure against the skill intensity of the firm. Figure 2 shows a positive correlation between either total exports or the number of export destinations of a firm, and its skill intensity (conditioned on firm's size, to control for any size effect). This descriptive evidence is in line with the existence of specific destination fixed export costs that are skill-intensive. This is consistent with the types of activities related to these fixed costs. For instance, marketing activities, required to adapt products to the taste of foreign consumers, or to fulfill standards and regulations in foreign markets, are intensive in skilled labor.

\footnotetext{
${ }^{5}$ Section 5 provides further details about our classification and methodology to compute the volatility of skilled and unskilled workers.

${ }^{6}$ We use the number of destination markets as a proxy for export sales because, as showed in Section 7, our results are mainly driven by the extensive margin of exports.
} 


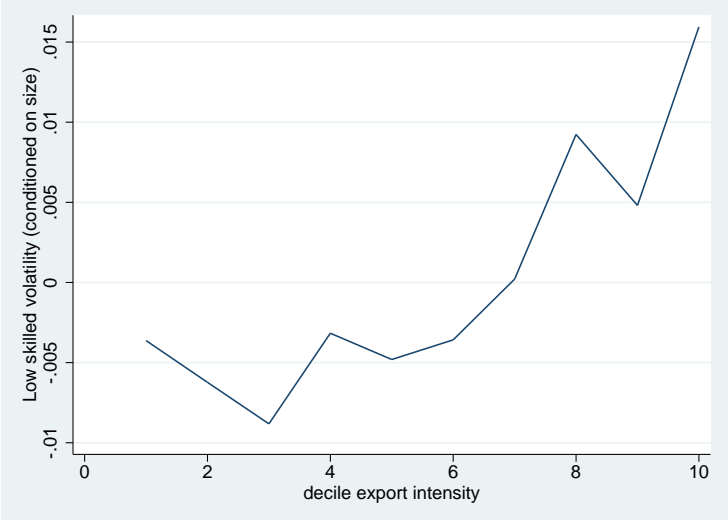

(a) Export and volatility of unskilled labor

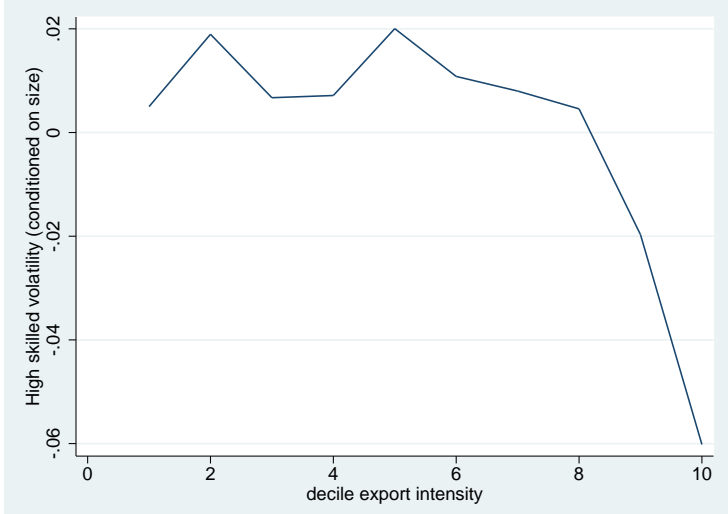

(c) Export and volatility of skilled labor

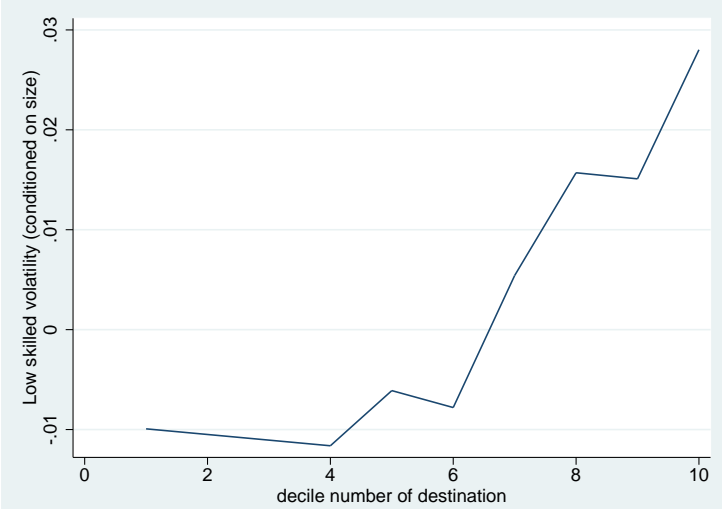

(b) N. dest. and volatility of unskilled labor

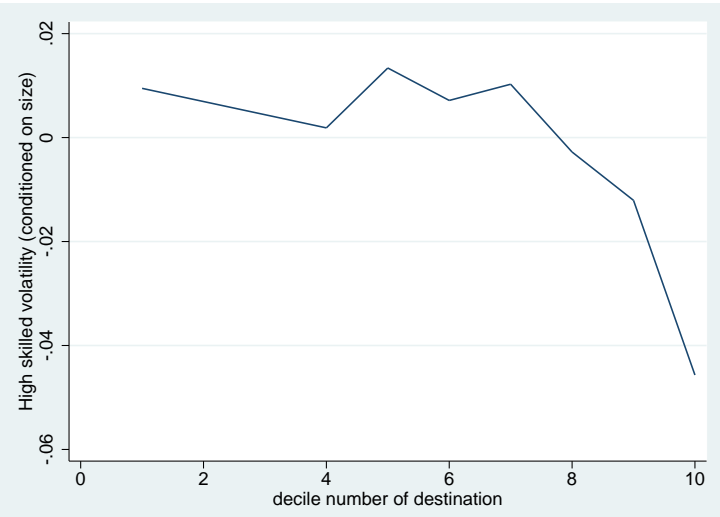

(d) N. dest. and volatility of skilled labor

Figure 1 - Export Intensity and Employment Volatility

Source: Authors' calculation using French firm level data for the period 1996-2007.

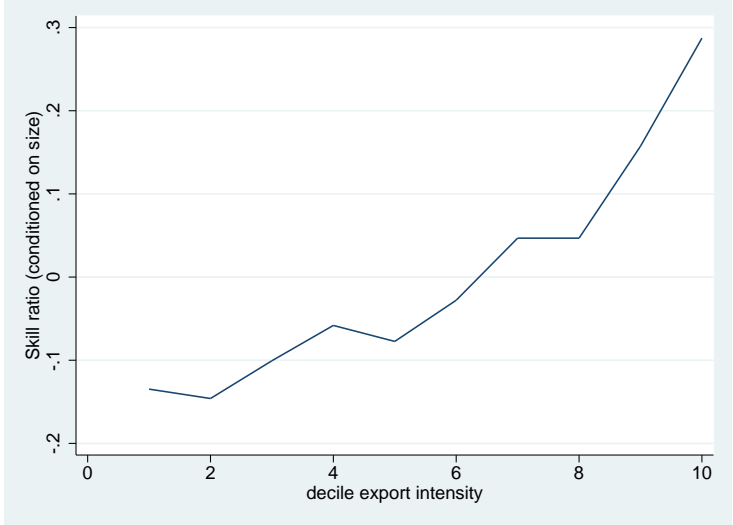

(a) Total export and skill intensity

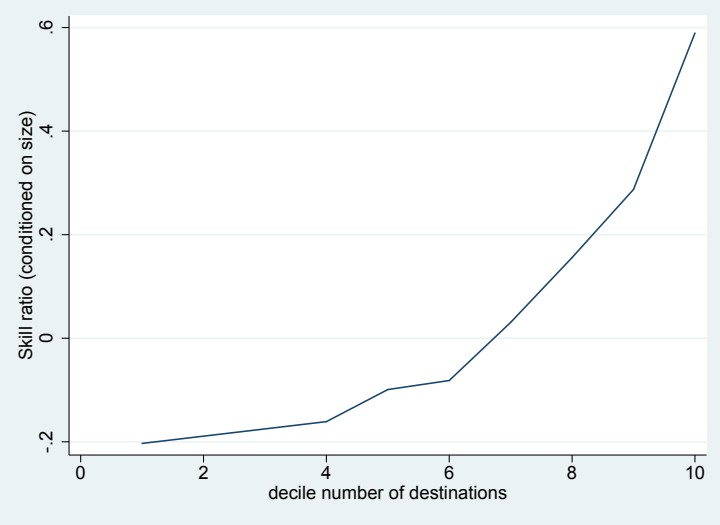

(b) N. dest. and skill intensity

Figure 2 - Export and skill intensity

Source: Authors' calculation using French firm level data for the period 1996-2007. 


\section{Theoretical motivation}

This section describes several possible theoretical mechanisms through which firms' export exposure may have a heterogeneous impact on the volatility of workers of different skills. Those channels arise mainly from two different sources of costs that firms may have to pay. The first group of channels is related to skilled-intensive fixed export costs that firms face in foreign markets. The second one is based on labor market frictions.

\subsection{Skilled intensive fixed export costs}

The first channel is related to the consequences of fixed costs that exporting firms face in foreign markets, and allows to disentangle the different impact of trade exposure on the volatility of skilled and unskilled labor. These are the product-destination fixed export costs that firms have to pay to adapt specific products to the standards and regulations and to the taste of foreign consumers in the destination countries.

Fixed export costs are skilled-intensive because they involve services and tasks that require more skilled labor such as marketing, research, communication with clients or intermediaries and distribution. This assumption on the existence of services costs to export that are skilled-intensive is in line with the model developed by Matsuyama (2007) and the evidence presented in Brambilla et al. (2012) and Verhoogen (2008). This assumption is also in line with the empirical evidence presented in the previous section.

In this framework where product-destination fixed export cost are skilled intensive, exporting firms facing shocks in their product-destination markets are expected to consequently adjust unskilled labor demand to a greater extent than skilled one, since the latter is a key asset to export. The main implication of this skilled-intensive fixed export costs mechanism is that large and multi-destination exporters, by facing a wider range of foreign shocks, experience a greater volatility for unskilled than for skilled workers.

In the Theoretical Appendix A1, we present a simple theoretical framework that rationalizes this mechanism based on the assumption of fixed export costs that are skilled-intensive 
through which firms' export sales have an unequal effect on the volatility of employment of different skills. This is the main channel that we test in the empirical analysis. In Section 7.1, we provide evidence of this theoretical mechanism by studying differences in employment volatility of different skilled workers across exporting firms, in relation to the number of destinations and products exported.

\subsection{Entry and exit dynamics in export markets}

A second channel is related with entry and exit dynamics in the export markets that can generate different adjustments of labor demand for workers of heterogeneous qualifications. The literature on export dynamics (Hess and Persson, 2011, Besedeš and Prusa, 2006a,b, Albornoz et al., 2012) highlighted that export activity is volatile due to the low probability of survival for some firms in the export market. Exporting firms might be entering and exiting specific destinations as a consequence of market shocks. This source of export volatility affects directly labor volatility. Whether the effect of entry and exit dynamics on the volatility of workers differs depending on their skills, it also depends on an additional assumption related to the first channel: skilled-intensive fixed export costs that are market-specific. In that case, firms whose export sales are churning due to entering to and exiting from foreign markets will have higher unskilled-labor volatility and lower skilled-labor volatility than firms that export continuously to the same destinations.

In Section 7.2, we test this mechanism relying on two measures of firm's export sales. One for export sales in continuously served destinations (i.e., countries always served by the firm over the entire sample period 1996-2007); the second one captures export sales in churning destinations computed over destinations where the firm entry/exit during the period.

\subsection{The volatility of demand}

The third mechanism is related to the volatility of output demand that drives the volatility of labor demand. The empirical works of Berman et al. (2015) and Vannoorenberghe (2012), relying on firm-level data, show that exporting firms, facing idiosyncratic shocks in their 
destination markets, exhibit higher domestic sales volatility. Considering the evidence showing that firms require more skilled labor to export (Brambilla et al., 2012 and Verhoogen, 2008), foreign demand volatility faced by exporting firms can also explain the differential effect of export sales on the volatility of skilled and unskilled labor.

\subsection{Labor market frictions and hiring costs}

An alternative channel through which firms' export sales may affect differently the volatility of skilled and unskilled labor is related to labor market frictions. Under a setting where labor markets are characterized by Diamond-Mortensen-Pissarides-type search and matching frictions (Pissarides, 1974; Davidson and Matusz, 1999), the existence of hiring, training and firing costs that are different across workers depending on their skills will affect the way in which firms adjust their demand of skilled and unskilled workers.

The works of Helpman et al. (2010) and Helpman et al. (2017) introduce search frictions in the heterogeneous firm trade models with workers of different skills. They show that in presence of firing and hiring costs, exporters will be not only more productive but also more skilled intensive and pay higher wages. When hiring and training costs are higher for skilled workers relative to unskilled ones, exporters facing foreign demand shocks may adjust more easily their labor demand for unskilled than skilled workers. Introducing this type of labor market frictions allows explaining why export sales have a greater impact on the volatility of unskilled labor relative to skilled one.

It is beyond the scope of this paper to test for this specific channel. However, our econometric strategy allows us to control for this mechanism by the inclusion of firm fixed effects when we compute the skilled and unskilled volatility measure (described in Section 5.1). Those firm fixed effects capture the unobserved time-invariant firm's characteristics like differences in fixed costs of hiring skilled and unskilled labor at the firm level. 


\section{Data}

Our empirical analysis combines two main sources of firm-level data from France for the period 1995-2007: the Déclaration Annuelle des Données Sociales (DADS) and the French Customs Data. DADS is an administrative dataset of matched employer-employee information collected by the INSEE (Institut Nationale de la Statistique et des Études Économique). It contains information on the employment and wage structure at the level of the firm, and the occupation category of its workers (4-digit classification). DADS also provides information on the firm's main industry of activity (NAF700, 4-digit industry classification). The data are based on mandatory reports of gross earnings, completed by employers to comply with French payroll taxes. All wage-paying individuals and legal entities established in France are required to file payroll declarations.

To disentangle the effects of export exposure across employment skills, we classify employees into two main categories according to their occupation's wage. Since we do not have direct information on the education of the worker, we consider as skilled those workers employed in occupations whose initial (average) wage is above the median wage in the sample. ${ }^{7}$ The others are classified as unskilled. This definition of skills reflects firms' appreciation of workers' qualifications. We also consider an alternative measure for skills, based on the type of occupations rather than average wages. More specifically, we distinguish between production and non-production workers according to the type of occupation within the firm.

Trade data come from the French Customs, which provides annual export data for French manufacturing firms by country of destination over the period 1995-2007. This database is quasi-exhaustive. Although reporting of firms having trade values below 39,000 euros (within the EU destination) or 1000 euros (extra-EU destinations) is not mandatory, there are in practice many observations below these thresholds. This suggests the quasi-exhaustive nature the French Customs data used here. ${ }^{8}$ The customs data are at the product level (8-

\footnotetext{
${ }^{7}$ We computed the average wage by occupation category (pcs 4-digit) in 1995 and classified skilled workers, those employees in occupations with average wage above the median.

${ }^{8}$ The different thresholds in compulsory custom declaration of export volumes is not an issue here. First, even if not compulsory, firms declare intra-EU export sales even if below the threshold. Second, we are interested
} 
digit Combined Nomenclature), which we translate into 6-digit Harmonized System (HS6), which gives us 5,349 categories. We aggregate trade data at the firm-year level in order to match with the employer-employee information in the DADS data set (as employer-employee data are firm-year specific). Since we are interested in measuring the effects of foreign shocks on labor market, we restrict our analysis to exporting firms, i.e. firms exporting at least one year over the period 1995-2007 (pure domestic firms do not face foreign demand shocks). ${ }^{9}$

\section{Estimation Strategy}

\subsection{Measuring Employment Volatility across Skills}

We measure volatility as the standard deviation of the residual component of the growth rate of firms' employment over the period 1996-2007. ${ }^{10}$ The residual growth rate comes from the following estimation which uses as a dependent variable the logarithm of growth rate of employment for skilled and unskilled workers respectively, in firm $i$ at time $t$ :

$$
\gamma_{i t}=\ln \left(E_{i t}\right)-\ln \left(E_{i t-1}\right)=\phi_{i}+\mu_{k t}+\sum_{d}^{D} \nu_{i d t}+v_{i t}
$$

This equation is estimated for skilled and unskilled labor separately. Therefore, $\gamma_{i t}$ is employment growth, for skilled and unskilled labor respectively, of firm i producing in 4-digit industry $k$ and time $t . E_{i t}$ is the total employment of skilled or unskilled labor of firm $i, \phi_{i}$ are firm fixed effects that capture the unobserved time-invariant firm's characteristics and $\mu_{k t}$ are sectoryear fixed effects. Importantly, firm fixed effects control for the average productivity of the firm. Our employment volatility measures should be interpreted as conditional on the average firm's productivity, which crucially reduces any omitted variable bias in the main estimation here in the total exports of the firm independently of the specific destination.

${ }^{9}$ The choice of using only exporting firms is also supported by the theoretical model reported in the Appendix section. From an empirical point of view, considering both exporters and domestic firms in the same regression would also imply a selection bias in estimation, and the need for one additional instrumental variable for the export status of the firm. However, for the interested reader, in appendix table A8 we show OLS econometric results using an estimation sample containing both exporter and domestic firm, and including the export status dummy as additional covariate.

${ }^{10}$ This is a standard measure of volatility used in the literature (Kurz and Senses (2016); Vannoorenberghe (2012)). Although data are available for the period 1995-2007, our estimation sample starts in 1996 as we lose the initial year in computing the growth rate. 
(see next section). Sector-year fixed effects capture any time-varying shocks affecting firms producing in the same sector (i.e., demand, supply or technology shocks). Lastly, to capture destination-specific time-varying shocks, we include destination-year dummies, $\nu_{i d t}{ }^{11}$ These dummies also capture the price indexes in the destination countries. The estimated residual from equation (1), $v_{i t}$, represents the deviation of employment growth from the firm average and from the sector average at year $t$. Volatility of high and low-skilled employment is then computed as the standard deviation of the estimated residual of growth rate for the period 1996-2007:

$$
\sigma_{i}=\sqrt{\frac{1}{11} \sum \hat{v}_{i t}^{2}}
$$

Given the structure of fixed effects included in equation (1), the measures of firm-level employment volatility for skilled and unskilled workers are already purged from firm unobservable characteristics and time-varying shocks across industries. ${ }^{12}$ Notice that the measure of volatility is not year-specific; the standard deviation is computed across years for every exporting firm. Our main identification strategy is thus based on a cross-sectional approach. To compute the standard deviation on a homogeneous time span, we only retain firms with non-missing employment data over the entire period 1996-2007. ${ }^{13}$ Appendix A2 (tables A1-A3) reports in-sample descriptive statistics for the main variables used in the empirical exercise.

\subsection{Identification strategy}

Following the theoretical framework in Section 3, we investigate the heterogeneous effect of firms' export sales on skilled and unskilled employment volatility using the following empirical

\footnotetext{
${ }^{11}$ This dummy is equal to one if a given firm $i$ exports into a specific destination $d$ at time $t$. Zero otherwise. $D$ is the total number of destinations $d$ contained in the French Custom database.

${ }^{12}$ As a robustness check, we also use the coefficient of variation of residual employment growth rates $v_{i t}$ as an alternative measure to the standard deviation. The results, reported in table A6, are robust to this check.

${ }^{13}$ In the Appendix, we report a robustness check using all firms, even those with employment data in only two years (unbalanced data). The results, reported in Table A7, are qualitatively the same.
} 
equation:

$$
\frac{\sigma_{i s}}{\sigma_{i u}}=\beta_{0}+\beta_{1} E_{x p o r t s_{i}}+\beta_{2} \text { Size }_{i}+\beta_{3} \text { Imports }_{i}+\alpha_{k}+\epsilon_{i}
$$

where $\sigma_{i s} / \sigma_{i u}$ is the ratio between skilled and unskilled employment volatility in firm $i$ as calculated in equation (2). The choice of a ratio is coherent with Proposition 2 in the theoretical framework reported in Appendix A1 and contributes to a proper identification strategy. ${ }^{14}$ Indeed, using the ratio considerably reduces any potential omitted variable problem, since any firm-specific factor affecting simultaneously a firm's skilled and unskilled labor demand will be cleaned out. Export sales, Exports, are measured as the logarithm of average export sales of a firm over the period 1996-2007; and $\mathrm{Size}_{i}$ is the logarithm of total employment in 1996. ${ }^{15}$ The heterogeneous effect of export exposure on the volatility of different skills might be driven by the outsourcing strategy of firms. If imported inputs are complements to skilled workers and/or substitute for unskilled ones, outsourcing intermediate goods from foreign countries might also have a heterogeneous effect on the volatility of employment. For this reason, we include as a control variable average imports of firm $i$ over the period 1996-2007 $\left(/ m p o r t s_{i}\right)$. This variable also controls for firm-specific foreign supply shocks. Finally, to account for unobservable industry specific factors, we control for industry fixed effects (2digit), $\alpha_{k}$. Therefore the specification in (3) captures variations in the relative volatility of skilled labor demand across firms within a 2-digit sector. The identification strategy using the across firms (within industry) variability in employment volatility is supported by the fact that a considerable amount of the overall variation in skilled and unskilled firm's employment growth is due to the between firms component (see table A3). $\beta_{1}$, the coefficient of interest, shows the effect of firms' exports on the relative volatility of skilled labor demand, conditional on firm size (as controlled by total employment).

\footnotetext{
${ }^{14}$ However, in Section 6.2 we also provide results using the volatility of skilled and unskilled labor demands separately rather than in ratio.

${ }^{15}$ We use employment in the initial year to reduce endogeneity concern for this control variable.
} 


\subsection{Identifying the Causal Effect of Export on Employment Volatility}

A potential endogeneity concern arises when studying the relationship between firms' exports and the volatility of employment. The possible impact of skill-neutral technological change is not a problem here. To the extent that (being skill-neutral) such a technological shock affects in the same way the volatility of labor demand irrespectively of skill level, it does not affect our dependent variable, which is expressed as a ratio between skill and unskilled labor demand volatility. However, the existence of skill-biased technical change is well documented (Autor et al., 2003, e.g.), and it may alter both firms' export intensity and the relative volatility of their demand for skilled labor. As many different patterns may arise, we remain agnostic as to the ensuing bias, and rely upon an instrumental variable approach to correct for it.

Two instrumental variables are used to capture the exogenous determinants of exports. The first one is the industry-specific Real Exchange Rate (RER), averaged over the period. It represents an exogenous foreign demand shock affecting firms across their export destinations. The industry-specific RER is obtained by averaging at NAF-700 4-digit level the specific RER faced by each exporting firm across its destinations markets. ${ }^{16}$ The second instrument is the initial level of the firm's exports, i.e. in 1995. Total exports of the firm at the beginning of the period is a good predictor of the average exports of the firm, and is not correlated with ex-post employment volatility since in building the employment volatility measure we always control for the average firm size through firm-fixed effects. See equation (1). The over-identified model enables us to obtain a Sargan test for the validity of these instruments.

While the relevance of these two instruments is reported at the bottom of the main table of results (see first-stage coefficients in Table 1 and in Table A4), their validity must be discussed carefully. The exclusion restriction assumption relies on the absence of any direct impact of the two instruments on the relative labor demand volatility of the firm. Conditioned

\footnotetext{
${ }^{16}$ The firm-level RER is calculated as the average RER that the exporting firm faces across all the export destinations in a year, using fixed initial weights across destinations. Then we take the average at the NAF-700 4-digit industry level of that firm-specific RER. Notice that each firm is associated with a unique NAF-700 4-digit industry.
} 
Figure 3 - Orthogonality of Instrumental Variables.

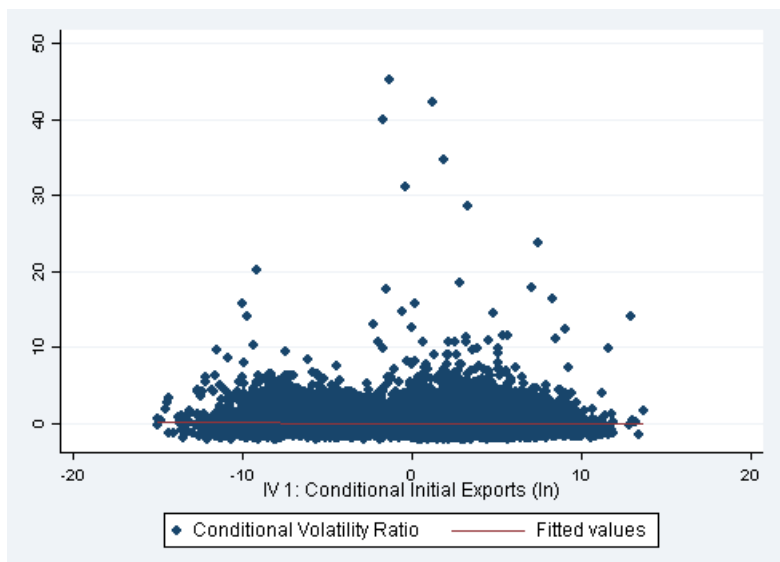

(a) Correlation between initial firm's exports and conditioned volatility ratio.

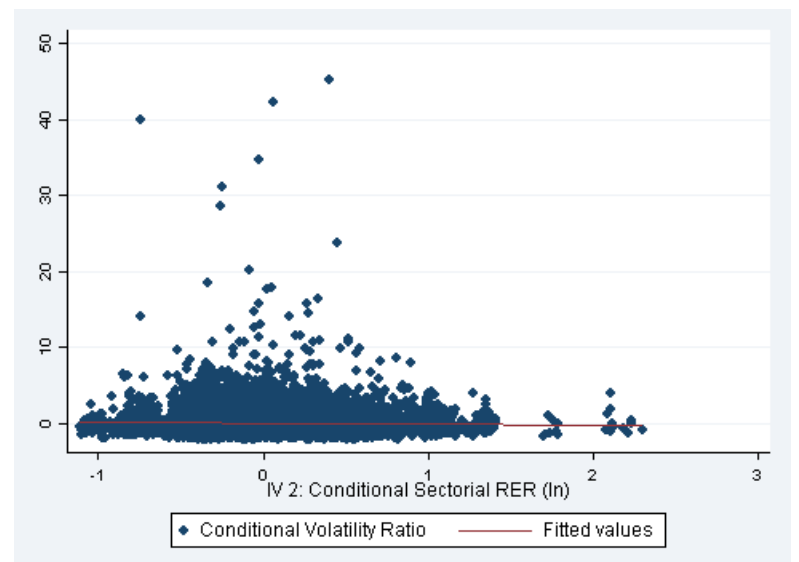

(b) Correlation between conditioned sectorial RER and conditioned volatility ratio.

on other covariates, the sector RER and the initial firm's exports must be uncorrelated with the relative employment volatility (i.e. they may affect the dependent variable only through the average export exposure of the firm). This is likely to be case in our empirical framework. The sector RER represents a foreign demand shock that plausibly affects the firm's labor demand only through a change in the foreign demand for the product exported by the firm. ${ }^{17}$ The initial level of imports of the firm can be considered exogenous because it is unlikely to affect the subsequent changes in the labor demand.

To support the validity of our instrumental variables, we show in Figure 3 the correlation between each of our instrument and the dependent variable (conditioning on other covariates to closely mimic the exclusion restriction assumption). The exogeneity of our instruments is qualitatively supported by the absence of correlation: the two instrumental variables are clearly uncorrelated with the dependent variable. The Sargan test of over-identifying restrictions reported in Table 1 further supports the validity of our instrumental variables.

\footnotetext{
17The sector RER may also affect the import demand of the firm and therefore its labor demand. However, this channel is captured by including in all regressions the firm's average imports.
} 


\section{Results}

\subsection{Relative Volatility of Skilled Labor Demand}

Table 1 presents the results for testing the effect of export sales on employment volatility across skills, based on equation (3). Our findings show that export sales have a negative and significant effect on the relative volatility of skilled labor demand (column 1 ). Within an industry and conditional on firm' size and imports, firms that are more exposed to exports have a smaller ratio of employment volatility (skilled/unskilled) relative to firms that export less. This result is in line with our theoretical motivation in section 3 and with Proposition 2 of Appendix A1. ${ }^{18}$ Since French-speaking destinations are likely to exhibit higher cultural proximity, perhaps reflected in the magnitude and nature of fixed export costs, we also run the estimate excluding these destinations. The coefficient of interest is smaller, but still significant (column 2).

As discussed above, these OLS estimates cannot be interpreted as causal, because of the possible endogeneity bias, we therefore rely on the IV estimations discussed above. The first-stage results, reported in Table A4 in the Appendix, support both the relevance of the two IVs and the absence of any concern about a weak instrument (F-stat above ten). Also, the Sargan test, reported at the bottom of Table 1 supports the validity of our instrumental variables. Column 3 of Table 1 reports the second-stage results for the IV estimates. Again, firms with a higher level of exports experience reduced relative volatility of skilled labor demand. However, the effects of export sales on the relative volatility of skilled labor demand is stronger in absolute value in the IV estimates. The downward bias in the absolute value of OLS estimates would be consistent, for instance, with a skill-biased technological change increasing the relative volatility of skilled labor demand, while boosting export intensity. To illustrate the economic significance, the result found in column 3 means that, for a given firm, doubling export sales results in relative volatility being reduced by 0.05 . This corresponds to a $15 \%$ lower relative volatility for a firm initially belonging to the first decile of relative

\footnotetext{
${ }^{18}$ It should be emphasized that our measure of firm-level employment volatility is already purged from firm and sector-year unobservable characteristics
} 
volatility, and to a 3\% lower volatility for a firm initially belonging to median relative volatility.

Given the increasing development of flexible forms of work, the volatility of employment may be disconnected from the volatility of the number of hours worked. We thus apply the same method, using this alternative measurement of labor input. The sample size is reduced by approximately one-fourth in this case, due to incomplete information on hours worked. The results, presented in the last two columns in Table 1 , are qualitatively similar to those based on employment, even though the impact of exports on relative volatility is stronger in absolute value. To allow comparability of coefficients, in column (4) we run the baseline 2SLS estimation on the volatility of residual employment growth, but using the sample of firms with non-missing information on the number of hours worked. Tables A5 and A6 in Appendix report additional robustness checks, using, respectively, an alternative definition of skills (production vs non-production workers), and an alternative volatility measure (coefficient of variation in the residual employment growth). The results are consistent with those reported in Table 1. While this is not at the core of our contribution, we find a strongly significant effect of firm size on relative volatility. As we check below when studying separately the volatility of demand for skilled and unskilled labor (see Table 5), larger firms tend to exhibit more stable labor demand for both categories, with a bigger firm's size coefficient for unskilled than for skilled workers. This explains the strong negative coefficient for firm size on relative volatility. ${ }^{19}$

In Table 2 we report robustness checks using different sample stratifications and empirical specification. In column (1), we drop the average firm's import from the set of control variable because the import intensity of the firm may also be an endogenous variable. In column (2), we add the unskilled intensity of the firm in 1995 as a further control. It is reassuring that these changes in the baseline empirical specification do not alter our results. Since in France firms up to 50 employees benefit from various ad-hoc administrative advantages, in columns (3) and (4) we replicate our baseline estimation for a sub-sample of firms with

\footnotetext{
${ }^{19}$ The import intensity of the firm has a negative but very weak coefficient, suggesting a marginal role for import intensity on the ratio of volatilities.
} 
respectively less and more than 50 employees over the entire period. ${ }^{20}$ As further stressed in section 7.3, our results hold for relatively large firms. The last column of Table 2 uses only full-time employment to compute skilled and unskilled volatility and results remain qualitatively identical. In Table 3 we report baseline results using the ratio of wage (rather than employment) volatility. It is interesting to notice that foreign demand shocks do not alter the relative volatility of wages. This suggests that firms react to foreign shocks by adjusting employment level rather than wages.

In Table 4 we take seriously the concern of endogeneity for the import intensity of the firm and instrument also the average firm's imports. We mimic the IV strategy adopted for the export intensity, and instrument the average import intensity of the firm over the period 1996-2007 by using the initial level of imports. Even by instrumenting both the export and the import intensity of the firm, our baseline result does not change: higher export intensity causes lower volatility ratio. It must be noticed that the introduction of the IV for imports does not alter the relevance and the validity of our IVs - see first stage results in the bottom part of Table $4 .{ }^{21}$

\subsection{Volatility of Employment in Levels}

As discussed above, using the ratio of volatilities as dependent variable is convenient for two reasons. First, it is coherent with the theoretical framework reported in appendix A1. Second, it mechanically controls for any firm-specific factor that affects in the same way the volatility of skilled and unskilled workers, hence reducing concern about possible omitted variables, and the bias that would ensue. Nevertheless, from an economic policy perspective, it is of great interest to test the effect of export sales on the volatility of skilled and unskilled workers separately. Beyond their relative levels, the question is whether the impact of exports on volatility of labor demand differs in sign or only in magnitude. To address this issue, we

\footnotetext{
${ }^{20}$ Firms crossing the threshold of 50 employees (from above or below) over the period 1996-2007 are not considered in this robustness check.

${ }^{21}$ First stage coefficients reported in the bottom part of Table 4 refer to the related endogenous variable. Namely, first stage coefficients for initial exports and RER refer to the first stage on export intensity, while coefficients on initial imports refers to the first stage on import intensity.
} 
Table 1 - Export sales and firms' employment volatility, skilled/unskilled.

\begin{tabular}{|c|c|c|c|c|c|c|}
\hline \multirow[t]{2}{*}{ Dep Var: } & \multicolumn{4}{|c|}{$\begin{array}{l}\text { S.D. residual employment growth } \\
\text { skilled/unskilled }\end{array}$} & \multicolumn{2}{|c|}{$\begin{array}{l}\text { S.D. residual hours workec } \\
\text { growth skilled/unskilled }\end{array}$} \\
\hline & $(1)$ & $(2)$ & (3) & $(4)$ & (5) & (6) \\
\hline Export Sales & $\begin{array}{c}-0.029 * * * \\
(0.005)\end{array}$ & & $\begin{array}{c}-0.050 * * * \\
(0.008)\end{array}$ & $\begin{array}{c}-0.052^{* * *} \\
(0.010)\end{array}$ & $\begin{array}{c}-0.051 * * * \\
(0.016)\end{array}$ & $\begin{array}{l}-0.086^{*} \\
(0.049)\end{array}$ \\
\hline Export (no French) & & $\begin{array}{c}-0.012 * * * \\
(0.003)\end{array}$ & & & & \\
\hline Firm' size & $\begin{array}{c}0.344 * * * \\
(0.020)\end{array}$ & $\begin{array}{c}0.332 * * * \\
(0.018)\end{array}$ & $\begin{array}{c}0.363 * * * \\
(0.032)\end{array}$ & $\begin{array}{c}0.349 * * * \\
(0.028)\end{array}$ & $\begin{array}{c}0.213 * * * \\
(0.062)\end{array}$ & $\begin{array}{c}0.247 * * * \\
(0.047)\end{array}$ \\
\hline Imports & $\begin{array}{l}-0.001 \\
(0.003)\end{array}$ & $\begin{array}{c}-0.004 * * \\
(0.002)\end{array}$ & $\begin{array}{c}0.004 \\
(0.004)\end{array}$ & $\begin{array}{c}0.001 \\
(0.004)\end{array}$ & $\begin{array}{c}0.000 \\
(0.006)\end{array}$ & $\begin{array}{c}0.011 \\
(0.011)\end{array}$ \\
\hline Industry FE & Yes & Yes & Yes & Yes & Yes & Yes \\
\hline Estimator & OLS & OLS & $2 S L S$ & $2 S L S$ & OLS & $2 S L S$ \\
\hline Sample & Full & Full & Full & $\begin{array}{l}\text { Non-missing } \\
\text { hours worked }\end{array}$ & Full & Full \\
\hline IV: RER & & & $\begin{array}{c}0.585^{* * *} \\
(0.106)\end{array}$ & $\begin{array}{c}0.576 * * * \\
(0.114)\end{array}$ & & $\begin{array}{c}0.576^{* * *} \\
(0.114)\end{array}$ \\
\hline IV: Export $(\mathrm{t}=0)$ & & & $\begin{array}{c}0.248 * * * \\
(0.018)\end{array}$ & $\begin{array}{c}0.251 * * * \\
(0.019)\end{array}$ & & $\begin{array}{c}0.251 * * * \\
(0.019) \\
\end{array}$ \\
\hline Observations & 17,694 & 17,694 & 17,694 & 13,118 & 13,118 & 13,118 \\
\hline R-squared & 0.056 & 0.055 & 0.039 & 0.037 & 0.028 & 0.000 \\
\hline F-stat first Stage & & & 103 & 85 & & 85 \\
\hline Sargan Test & & & 0.719 & 0.393 & & 0.958 \\
\hline
\end{tabular}

Notes: The dependent variable is the relative volatility of skilled labor demand, defined as the ratio between skilled and unskilled employment volatility (columns (1) to (4)) and hours worked volatility (columns (5) and (6)). Firm level volatility of employment is computed as the standard deviation of the estimated residual of employment (or hours worked) growth rate on firm, sector-year fixed effects and destination-year dummies for the period 1996-2007. Export sales (imports) are measured by the logarithm of average exports (imports) of the firm during the period. Firm size is measured as the logarithm of total employment of the firm in the initial year. Standard errors are bootstrapped in columns (1), (2) and (5) and clustered by sector in columns (3), (4) and (6).

estimate the effect of export sales on the volatility of labor demand, separately for skilled and unskilled workers. For each of these two categories, we thus estimate the following equation:

$$
\sigma_{i}=\beta_{0}+\beta_{1} \text { Exports }_{i}+\beta_{2} \text { Size }_{i}+\beta_{3} \text { Imports }_{i}+\alpha_{k}+\epsilon_{i}
$$

where the dependent variable, $\sigma_{i}$, is our firm-level employment volatility measure (described in Section 5). ${ }^{22}$ The results reported in Table 5 support the theoretical prediction of Proposition 1: for a given firm's size, higher exports lead to higher volatility of unskilled employment. For skilled workers, in contrast, no clear prediction emerged from our theoretical analysis. Interestingly, we find that exports decrease the volatility of skilled workers - see columns (1)

\footnotetext{
${ }^{22}$ We also followed Kurz and Senses (2016) and estimate the volatility of total employment. Results are
} available upon request. 
Table 2 - Export sales and firms' employment volatility, skilled/unskilled. Robustness checks

\begin{tabular}{|c|c|c|c|c|c|}
\hline \multirow[t]{2}{*}{$\overline{\overline{\text { Dep Var: }}}$} & \multicolumn{5}{|c|}{$\begin{array}{l}\text { S.D. residual employment growth } \\
\text { skilled/unskilled }\end{array}$} \\
\hline & $(1)$ & (2) & (3) & (4) & (5) \\
\hline Export Sales & $\begin{array}{c}-0.046 * * * \\
(0.007)\end{array}$ & $\begin{array}{c}-0.050 * * * \\
(0.008)\end{array}$ & $\begin{array}{l}-0.009 \\
(0.012)\end{array}$ & $\begin{array}{c}-0.071 * * \\
(0.028)\end{array}$ & $\begin{array}{c}-0.040 * * * \\
(0.007)\end{array}$ \\
\hline Firm' size & $\begin{array}{c}0.368 * * * \\
(0.035)\end{array}$ & $\begin{array}{c}0.354 * * * \\
(0.034)\end{array}$ & $\begin{array}{c}0.524 * * * \\
(0.061)\end{array}$ & $\begin{array}{l}-0.017 \\
(0.051)\end{array}$ & $\begin{array}{c}0.279 * * * \\
(0.051)\end{array}$ \\
\hline Imports & & $\begin{array}{c}0.004 \\
(0.004)\end{array}$ & $\begin{array}{l}-0.001 \\
(0.005)\end{array}$ & $\begin{array}{l}-0.005 \\
(0.024)\end{array}$ & $\begin{array}{l}0.010^{*} \\
(0.005)\end{array}$ \\
\hline Unskilled Intensity $(\mathrm{t}=0)$ & & $\begin{array}{c}0.342^{* * *} \\
(0.104)\end{array}$ & & & \\
\hline Industry FE & Yes & Yes & Yes & Yes & Yes \\
\hline Estimator & $2 S L S$ & 2SLS & $2 S L S$ & 2SLS & $2 S L S$ \\
\hline IV: RER & $\begin{array}{c}0.830^{* * *} \\
(0.088)\end{array}$ & $\begin{array}{c}0.607^{* * *} \\
(0.091)\end{array}$ & $\begin{array}{c}0.561^{* * *} \\
(0.172)\end{array}$ & $\begin{array}{c}0.552^{* * *} \\
(0.150)\end{array}$ & $\begin{array}{c}0.583^{* * *} \\
(0.104)\end{array}$ \\
\hline IV: Export $(\mathrm{t}=0)$ & $\begin{array}{c}0.289 * * * \\
(0.015)\end{array}$ & $\begin{array}{c}0.247 * * * \\
(0.018)\end{array}$ & $\begin{array}{c}0.224 * * * \\
(0.016)\end{array}$ & $\begin{array}{c}0.303 * * * \\
(0.025)\end{array}$ & $\begin{array}{c}0.248 * * * \\
(0.018)\end{array}$ \\
\hline$\overline{\text { Sample }}$ & Baseline & Baseline & $\begin{array}{l}\text { Firm size } \\
\text { below } 50\end{array}$ & $\begin{array}{l}\text { Firm size } \\
\text { above } 50\end{array}$ & $\begin{array}{l}\text { Full-time } \\
\text { employment }\end{array}$ \\
\hline Observations & 17694 & 17694 & 10667 & 3226 & 17487 \\
\hline R-squared & 0.039 & 0.041 & 0.055 & 0.008 & 0.015 \\
\hline F-stat first Stage & 178 & 96 & 117 & 86 & 96 \\
\hline Sargan Test & 0.777 & 0.340 & 0.765 & 0.600 & 0.323 \\
\hline
\end{tabular}

Notes: The dependent variable in columns (1)-(5) is the relative volatility of skilled labor demand, defined as the ratio between skilled and unskilled employment volatility. In column (5) the relative volatility has been calculated on full-time workers only. Firm level volatility of employment is computed as the standard deviation of the estimated residual of employment growth rate on firm, sector-year fixed effects and destination-year dummies for the period 1996-2007. Export sales (imports) are measured by the logarithm of average exports (imports) of the firm during the period. Firm size is measured as the logarithm of total employment of the firm in the initial year. The share of unskilled workers over total firm's employment is measured in the initial year. Standard errors are clustered by sector.

and (3) in Table 5. This last result holds even when using specific high-skilled occupations' volatility: (i) managers in column (5), (ii) ICT workers in column (6), and (iii) engineers and lawyers in column (7). The impact of exports on employment volatility thus differs in sign, and not only in magnitude, across labor categories: it is positive for unskilled labor, but negative for skilled labor.

\section{Testing the Mechanisms at Play}

In this section we explore the possible channels of transmission. First, we consider how the degree of diversification, in terms of destination markets and portfolio of exported products, 
Table 3 - Export sales and firms' wage volatility, skilled/unskilled.

\begin{tabular}{lccc}
\hline \hline Dep Var: & \multicolumn{3}{c}{$\begin{array}{c}\text { S.D. residual wage growth } \\
\text { skilled/unskilled }\end{array}$} \\
\hline & $(1)$ & $(2)$ & $(3)$ \\
\hline Export Sales & 0.015 & & 0.044 \\
Export Sales(no French) & $(0.026)$ & 0.004 & $(0.033)$ \\
Firm' size & & $(0.023)$ & \\
& $-0.379 * * *$ & $-0.398 * * *$ & $-0.353^{* *}$ \\
Imports & $(0.125)$ & $(0.089)$ & $(0.140)$ \\
& -0.032 & -0.039 & -0.022 \\
Industry FE & $(0.024)$ & $(0.026)$ & $(0.017)$ \\
Estimator & Yes & Yes & Yes \\
IV: RER & OLS & OLS & $2 S L S$ \\
IV: Export (t=0) & & & $0.564 * * *$ \\
& & & $0.113)$ \\
Observations & & & $0.252^{* * *}$ \\
R-squared & 8758 & $0.017)$ \\
F-stat first Stage & 0.011 & 0.011 & 8758 \\
Sargan Test & & & 0.004 \\
\hline \hline
\end{tabular}

Notes: The dependent variable in columns (1)-(3) is the relative volatility of hourly wage, defined as the ratio between skilled and unskilled hourly wage volatility in the firm. Firm level volatility of hourly wage is computed as the standard deviation of the estimated residual of hourly growth rate on firm, sector-year fixed effects and destination-year dummies for the period 1996-2007. Export sales (imports) are measured by the logarithm of average exports (imports) of the firm during the period. Firm size is measured as the logarithm of total employment of the firm in the initial year. Standard errors are clustered by sector.

is related to the volatility of its employment. Second, we explore the relationship between a firm's dynamics into destination markets (entry and exit) and employment volatility. Third, we examine the heterogeneous effect that a firm's size might have on the volatility of employment.

\subsection{Number of Destinations and Products Exported}

In the previous section, we showed robust and stable evidence on the differentiated effect of export sales on the volatility of employment of different skill levels. Our theoretical framework reported in section 3 highlights that the main source of this heterogeneous effect comes from skilled-labor specific requirements in fixed (rather than variable) export costs. This section provides reinforcing evidence of the theoretical mechanism by looking at differences in employment volatility across exporting firms depending on the number of destinations and 
Table 4 - Export sales and firms' employment volatility, skilled/unskilled. Robustness checks by instrumenting also firm's imports.

\begin{tabular}{lccc}
\hline \hline Dep Var: & \multicolumn{3}{c}{ S.D. residual growth of: } \\
\cline { 2 - 4 } & $\begin{array}{c}\text { skilled/unskilled } \\
\text { employment }\end{array}$ & $\begin{array}{c}\text { skilled/unskilled } \\
\text { hours worked }\end{array}$ & $\begin{array}{c}\text { prod./non-prod. } \\
\text { employment }\end{array}$ \\
\hline & $(1)$ & $(2)$ & $(3)$ \\
\hline Export Sales & $-0.039^{* * *}$ & -0.067 & $-0.028^{* * *}$ \\
Firm' size & $(0.010)$ & $(0.060)$ & $(0.009)$ \\
& $0.375^{* * *}$ & $0.270^{* *}$ & $0.275^{* * *}$ \\
Imports & $(0.016)$ & $(0.106)$ & $(0.016)$ \\
& -0.007 & -0.011 & $-0.011^{* *}$ \\
Industry FE & $(0.006)$ & $(0.038)$ & $(0.006)$ \\
Estimator & Yes & Yes & Yes \\
IV: RER & $2 S L S$ & $2 S L S$ & $0.716^{* * *}$ \\
& $0.715^{* * *}$ & $0.712^{* * *}$ & $(0.049)$ \\
IV: Export $(\mathrm{t}=0)$ & $(0.049)$ & $(0.055)$ & $0.257^{* * *}$ \\
& $0.258^{* * *}$ & $0.262^{* * *}$ & $(0.003)$ \\
IV: Import $(\mathrm{t}=0)$ & $(0.003)$ & $(0.003)$ & $0.081^{* * *}$ \\
& $0.080^{* * *}$ & $0.078^{* * *}$ & $(0.003)$ \\
\hline Observations & $(0.003)$ & $(0.004)$ & 17763 \\
R-squared & 17694 & 13118 & 0.046 \\
F-stat first Stage & 0.054 & 0.028 & 1404 \\
Sargan Test & 1402 & 1059 & 0.228 \\
\hline \hline
\end{tabular}

Notes: The dependent variable in columns (1)-(3) is the relative volatility of skilled labor demand, defined as the ratio between skilled and unskilled employment volatility (column 1), skilled and unskilled hours worked volatility (column 2), production and non-production employment volatility. Firm level volatility of employment is computed as the standard deviation of the estimated residual of employment growth rate on firm, sector-year fixed effects and destination-year dummies for the period 1996-2007. Export sales (imports) are measured by the logarithm of average exports (imports) of the firm during the period. Firm size is measured as the logarithm of total employment of the firm in the initial year. Standard errors are clustered by sector.

products exported (extensive margin channel). The logic behind this exercise is that each firm adapts its products to a specific destination market. Therefore, the fixed export cost varies by destination and product.

Table 6 presents the results. Columns (1) and (2) quantify the effect of portfolio diversification in the destination country, using exports per market and total number of destinations by firm respectively. Firms that are more diversified in export destinations are found to have a weaker relative volatility of skilled labor demand. Then, in column (3), we consider the role of diversification as revealed by the number of exported products. A firm's export scope is also negatively correlated with the relative volatility of skilled labor demand. In the last two columns, we gradually include all proxies for portfolio diversification. The results suggest that 
Table 5 - Employment Volatility: Skilled versus Unskilled

\begin{tabular}{|c|c|c|c|c|c|c|c|}
\hline \multirow[t]{2}{*}{$\overline{\text { Dep Var: }}$} & \multicolumn{7}{|c|}{ S.D. of residual employment growth for the following categories: } \\
\hline & Skilled & Unskilled & Non-Prod & Prod & Managers & Techies & $\begin{array}{l}\text { Engineers } \\
\text { \& Lawyers }\end{array}$ \\
\hline & $(1)$ & $(2)$ & (3) & $(4)$ & (5) & (6) & $(7)$ \\
\hline Export Sales & $\begin{array}{c}-0.009 * * * \\
(0.002)\end{array}$ & $\begin{array}{c}0.003 * * * \\
(0.001)\end{array}$ & $\begin{array}{c}-0.008 * * * \\
(0.001)\end{array}$ & $\begin{array}{l}0.003 * \\
(0.001)\end{array}$ & $\begin{array}{c}-0.007^{* * *} \\
(0.001)\end{array}$ & $\begin{array}{c}-0.013 * * * \\
(0.003)\end{array}$ & $\begin{array}{c}-0.006 * * * \\
(0.002)\end{array}$ \\
\hline Firm' size & $\begin{array}{c}-0.026 * * * \\
(0.005)\end{array}$ & $\begin{array}{c}-0.073 * * * \\
(0.004)\end{array}$ & $\begin{array}{c}-0.031 * * * \\
(0.004)\end{array}$ & $\begin{array}{c}-0.075^{* * *} \\
(0.004)\end{array}$ & $\begin{array}{c}0.002 \\
(0.006)\end{array}$ & $\begin{array}{c}0.009 \\
(0.008)\end{array}$ & $\begin{array}{c}0.046 * * * \\
(0.009)\end{array}$ \\
\hline Imports & $\begin{array}{c}0.001 \\
(0.001)\end{array}$ & $\begin{array}{l}-0.000 \\
(0.000)\end{array}$ & $\begin{array}{c}-0.000 \\
(0.001)\end{array}$ & $\begin{array}{l}-0.000 \\
(0.000)\end{array}$ & $\begin{array}{c}0.003 * * * \\
(0.001)\end{array}$ & $\begin{array}{c}0.004 * * * \\
(0.001)\end{array}$ & $\begin{array}{c}0.007 * * * \\
(0.001)\end{array}$ \\
\hline Industry FE & Yes & Yes & Yes & Yes & Yes & Yes & Yes \\
\hline Estimator & 2SLS & 2SLS & 2SLS & 2SLS & 2SLS & 2SLS & 2SLS \\
\hline Observations & 17,703 & 18,072 & 17,780 & 18,064 & 17,583 & 16,987 & 12,260 \\
\hline R-squared & 0.042 & 0.258 & 0.066 & 0.244 & 0.055 & -0.009 & 0.046 \\
\hline
\end{tabular}

Notes: The dependent variable is the logarithm of firm level volatility of labor computed as the standard deviation of the estimated residual of employment growth rate on firm, sector-year fixed effects and destination dummies for the period 1996-2007. Export sales are measured by the logarithm of average exports of the firm during the period and firm size is measured as the logarithm of total employment of the firm in the initial year. Standard errors are clustered by sector in all columns.

diversification in destination markets matters most in explaining the heterogeneous effect of export sales on employment volatility across skills. These findings support our theoretical framework assuming skill-intensive fixed export costs: it is the number of destinations (not the intensive margin of exports), and therefore the number of destination-specific fixed costs to cope with, that matters for employment volatility ratio.

\subsection{Entry and Exit from Export Markets}

Another possible mechanism driving our findings is that employment volatility can be related to entry into and exit from the destination market. Firms in our sample might change their export status several times, entering and exiting some destinations, as a consequence of specific market shocks. The export sales in churning destinations might be associated with greater unskilled-worker volatility than export sales in continuous destinations.

We test for this channel by using two measures of a firm's export sales. The first measure is based on exports to destinations always served by the firm over the entire period 19962007 (continuous). The other measure captures a firm's exports to entry/exit destinations 
Table 6 - Export sales and firms' employment volatility, skilled/unskilled. Testing the mechanism.

\begin{tabular}{lccccc}
\hline \hline Dep Var: & \multicolumn{4}{c}{ S.D. residual employment growth, skilled/unskilled } \\
\hline & $(1)$ & $(2)$ & $(3)$ & $(4)$ & $(5)$ \\
\hline Export per market & $-0.032^{* * *}$ & & & -0.009 & -0.008 \\
& $(0.008)$ & & & $(0.008)$ & $(0.008)$ \\
N. destinations & & $-0.130^{* * *}$ & & $-0.124 * * *$ & $-0.090^{* *}$ \\
& & $(0.012)$ & & $(0.015)$ & $(0.040)$ \\
N. products & & & $-0.097^{* * *}$ & & -0.029 \\
& & & $(0.012)$ & & $(0.035)$ \\
Firm's size & $0.333^{* * *}$ & $0.355^{* * *}$ & $0.353^{* * *}$ & $0.358^{* * *}$ & $0.358^{* * *}$ \\
& $(0.014)$ & $(0.016)$ & $(0.014)$ & $(0.020)$ & $(0.020)$ \\
Imports & $-0.005^{* *}$ & 0.001 & 0.001 & 0.001 & 0.002 \\
& $(0.003)$ & $(0.002)$ & $(0.003)$ & $(0.003)$ & $(0.003)$ \\
\hline Industry FE & Yes & Yes & Yes & Yes & Yes \\
Estimator & OLS & OLS & OLS & OLS & OLS \\
\hline Observations & 17694 & 17694 & 17694 & 17694 & 17694 \\
R-squared & 0.036 & 0.058 & 0.058 & 0.056 & 0.058 \\
\hline \hline
\end{tabular}

Notes: The dependent variable is the ratio between skilled and unskilled employment volatilities. Firm-level volatility of employment is computed as the standard deviation of the estimated residual of employment growth rate on firm, sector-year fixed effects and destination-year dummies for the period 1996-2007. Export per market is the ratio between total export and the number of destinations (mean over the period). The number of destinations is the average number of destinations served by the firm over the period. The number of products is the average number of HS6 items exported over the period. Firm' size is measured as the logarithm of total employment of the firm in the initial year. Standard errors are bootstrapped in all columns.

(churning). Column 1 in Table 7 shows the results. Export sales to continuous destinations have a negative coefficient, but smaller (in absolute value) than export sales to churning destinations. This shows that unskilled employment volatility is more affected than skilled employment volatility, in particular for churning destinations.

Churning destinations, arguably, are the most complicated to reach. Therefore, we also test for the differential effect of export sales to EU versus non-EU destinations. Because of the Single Market, similar cultures and tastes, we expect EU-destinations to be more easily accessible for French firms than non-EU destinations. Additionally, since French firms should face higher uncertainty (greater demand shocks) in more difficult and remote markets, such as extra-EU destinations, the associated fixed costs should be greater. Column (2) in Table 7 shows that the export sales towards more difficult markets (extra-EU) has a stronger effect on volatility ratio than export sales in "easier" markets. 
Table 7 - Export sales and firms' employment volatility, skilled/unskilled by type of exports.

\begin{tabular}{lcc}
\hline \hline Dep Var: & \multicolumn{2}{c}{$\begin{array}{c}\text { S.D. residual employment } \\
\text { skilled/unskilled }\end{array}$} \\
\hline & $(1)$ & $(2)$ \\
Export Sales (continuous) & $-0.008^{* * *}$ & \\
Export Sales (churning) & $(0.002)$ & \\
& $-0.025^{* * *}$ & \\
Export Sales (EU) & $(0.006)$ & $-0.006^{* *}$ \\
& & $(0.003)$ \\
Export Sales (extra EU) & & $-0.020^{* * *}$ \\
& & $(0.004)$ \\
Firm' size & $0.350^{* * *}$ & $0.343^{* * *}$ \\
& $(0.020)$ & $(0.019)$ \\
Imports & -0.001 & -0.002 \\
& $(0.003)$ & $(0.003)$ \\
\hline Industry FE & Yes & Yes \\
Estimator & OLS & OLS \\
\hline Observations & 17,694 & 17,694 \\
R-squared & 0.057 & 0.056 \\
\hline \hline
\end{tabular}

Notes: The dependent variable is the ratio between skilled and unskilled employment volatility. Firm-level volatility of employment is computed as the standard deviation of the estimated residual of employment growth rate on firm, sector-year fixed effects and destination-year dummies for the period 1996-2007. Export sales are measured by the logarithm of average exports of the firm during the period by type of destination. Continuous destinations are those in which the firm exports continuously over the period, while churning destinations are those in which the firm occasionally exports. EU and non-EU export sales refer to EU and non-EU destination country exports, respectively. Firm' size is measured as the logarithm of total employment of the firm in the initial year. Standard errors are bootstrapped in all columns.

\subsection{Testing for Firm Size}

Since firms exporting to more destinations tend to be larger, this section tests for the heterogeneous effect of export sales on the volatility of employment of different skills depending on the initial size of the firm. We classify firms into three categories of initial size measured as the total employment of the firm in the initial year: big (initial total employment above the $75^{\text {th }}$ percentile), medium (between the $25^{\text {th }}$ and $75^{\text {th }}$ percentile) and small firms. We then interact export sales with these three size bins.

The results presented in Table 8 show that the effect of export sales on the relative volatility of skilled labor demand is significant only for large firms. 
Table 8 - Export sales and firms' employment volatility by firms' size.

\begin{tabular}{lcc}
\hline \hline Dep Var: & \multicolumn{3}{c}{$\begin{array}{c}\text { S.D. residual employment growth } \\
\text { skilled/unskilled }\end{array}$} \\
\hline & $(1)$ & $(2)$ \\
\hline Export Sales $\times$ Big & $-0.065^{* * *}$ & $-0.077^{* * *}$ \\
Export Sales $\times$ Medium & $(0.005)$ & $(0.011)$ \\
& 0.003 & 0.012 \\
Export Sales $\times$ Small & $(0.004)$ & $(0.012)$ \\
Imports & 0.031 & 0.044 \\
& $(0.033)$ & $(0.060)$ \\
Industry FE & -0.004 & -0.001 \\
Estimator & $(0.003)$ & $(0.004)$ \\
\hline Observations & Yes & Yes \\
R-squared & OLS & $2 S L S$ \\
\hline \hline
\end{tabular}

Notes: The dependent variable is the ratio between skilled and unskilled employment volatility. Firm-level volatility of employment is computed as the standard deviation of the estimated residual of employment growth rate on firm, sector-year fixed effects and destination-year dummies for the period 1996-2007. Export sales are measured by the logarithm of average exports of the firm during the period by type of destination. Big firms are those with initial total employment above the $75^{\text {th }}$ percentile. Small firms are those with initial total employment below the $25^{\text {th }}$ percentile. Medium-sized firms are those in between. Size bins included in the estimation but not reported. Standard errors are bootstrapped in column (1) and clustered by sector in column (2).

\section{Alternative Explanations}

In the previous section, we proposed different mechanisms to explain the heterogeneous impact of firms' export sales on the ratio of skilled over unskilled labor volatility. However, other forces might be driving our results. This section accounts for additional robustness checks and shows that our initial findings continue to hold.

\subsection{The role of MNFs}

Since multinational firms (MNFs) can adjust employment across affiliates (plants) and countries, this could bias our results. We therefore test the robustness of our results to the exclusion of MNFs. To identify MNFs, we combine our main dataset with the Enquete Echanges Internationaux Intra-Groupe provided by the French Office of Industrial Studies and Statistics (SESSI). ${ }^{23}$ The results, presented in Table 9, are very similar to those on the

\footnotetext{
${ }^{23}$ This dataset is based on a firm-level survey of manufacturing firms belonging to groups with at least one affiliate in a foreign country and with international transactions totaling at least one million euros. The survey year is 1998. The data provide a good representation of the activity of international groups located in France. These data cover around $82 \%$ of total trade flows by MNFs, and $55 \%$ and $61 \%$ of total French imports and
} 
full sample. Thus we can conclude that the impact of export sales on the relative volatility of skilled labor demand is not driven by the specific characteristics of French MNFs.

Table 9 - Export sales and firms' employment volatility, skilled/unskilled. Robustness check excluding MNEs.

\begin{tabular}{|c|c|c|c|}
\hline \multirow[t]{2}{*}{ Dep Var: } & \multicolumn{3}{|c|}{$\begin{array}{l}\text { S.D. residual employment growth } \\
\text { skilled/unskilled }\end{array}$} \\
\hline & (1) & (2) & (3) \\
\hline Export Sales & $\begin{array}{c}-0.022 * * * \\
(0.005)\end{array}$ & & $\begin{array}{c}-0.041 * * * \\
(0.009)\end{array}$ \\
\hline Export Sales (no French) & & $\begin{array}{c}-0.009 * * * \\
(0.003)\end{array}$ & \\
\hline Firm' size & $\begin{array}{c}0.374 * * * \\
(0.022)\end{array}$ & $\begin{array}{c}0.366 * * * \\
(0.017)\end{array}$ & $\begin{array}{c}0.390 * * * \\
(0.016)\end{array}$ \\
\hline Imports & $\begin{array}{l}-0.002 \\
(0.003)\end{array}$ & $\begin{array}{l}-0.004 \\
(0.003)\end{array}$ & $\begin{array}{c}0.003 \\
(0.004)\end{array}$ \\
\hline Industry FE & Yes & Yes & Yes \\
\hline Estimator & OLS & OLS & 2SLS \\
\hline Observations & 16,825 & 16,825 & 16,825 \\
\hline R-squared & 0.062 & 0.062 & 0.061 \\
\hline
\end{tabular}

Notes: The dependent variable is the ratio between skilled and unskilled employment volatility. Firm-level volatility of employment is computed as the standard deviation of the estimated residual of employment growth rate on firm, sector-year fixed effects and destination-year dummies for the period 1996-2007. Export sales are measured by the logarithm of average exports of the firm during the period and firm size is measured as the logarithm of total employment of the firm in the initial year. Standard errors are bootstrapped in columns (1) and (2) and clustered by sector in column (3).

\subsection{Controlling for Firm Productivity}

More productive firms are more skill-intensive and export to more destinations. Hence, the different level of productivity across exporting firms may explain the heterogeneous effect of export sales on the volatility of skilled and unskilled labor. It is important to stress that our dependent variable is constructed so that it is already purged from firms' unobservable time-invariant characteristics (i.e. average productivity). Additionally, all estimations also control for differences in firm's size, through total employment and total imports, which are both positively correlated with firm productivity.

Nevertheless, in this section, we go one step further and explicitly deal with potential omitted variable concerns that might affect the previous results, and include labor productivity. To exports respectively. 
add information on firms' value added, we match our main dataset with the Annual French Business Surveys (EAE), available from INSEE. This survey, of firms with more than 25 employees, allows us to include information on firms' value added and labor productivity (computed as the average ratio of value added over total employment of the firm over the period). Since this implies restricting the sample to exporters with more than 25 employees that have manufacturing as their main activity, the number of observations is reduced by almost one half.

The results are presented in Table 10. Despite the reduction in the number of observations, our coefficient of interest remains negative and significant, implying that within an industry firms with greater export sales have a lower relative volatility of skilled labor demand with respect to smaller exporting firms. These findings confirm that the previous results are not driven by differences in firm productivity and that they do not suffer from omitted variable concerns.

\subsection{The Impact of China's Accession to the WTO}

This section considers whether the exogenous trade shock related to the admission of China to the WTO in December 2001 might drive some of our results. The period after its entrance is characterized by stronger export opportunities for French firms. In fact, the tariffs faced by French firms were much reduced.

In order to see if our findings are affected by this exogenous export shock, we estimate our main specifications on two different sub-samples: before (1996-2001) and after (20022007) the accession of China to the WTO. All the variables are then computed for these two sub-sample periods. The results are presented in Table 11. Estimates are consistent but less precise for the period 1996-2001; only the OLS coefficients are significant in this case (column 1 and 2). For the period 2002-2007, the coefficient of firms' export sales remains negative and significant for both OLS and IV estimates (columns 4 and 6). 
Table 10 - Export sales and firms' employment volatility, skilled/unskilled. Controlling for labor productivity.

\begin{tabular}{lccc}
\hline \hline Dep Var: & \multicolumn{3}{c}{$\begin{array}{c}\text { S.D. residual employment growth } \\
\text { skilled/unskilled }\end{array}$} \\
\hline & $(1)$ & $(2)$ & $(3)$ \\
\hline Export Sales & $-0.045^{* * *}$ & & $-0.063^{* * *}$ \\
& $(0.008)$ & $0.021)$ \\
Export Sales (no French) & & $-0.019^{* * *}$ & \\
& & $(0.005)$ & $0.219^{* * *}$ \\
Firm' size & $0.203^{* * *}$ & $0.185^{* * *}$ & $(0.044)$ \\
& $(0.023)$ & $(0.024)$ & -0.002 \\
Imports & $-0.009 *$ & $-0.015^{* * *}$ & $(0.007)$ \\
& $(0.005)$ & $(0.005)$ & -0.001 \\
Firm Labor Productivity & -0.001 & -0.001 & $(0.001)$ \\
& $(0.002)$ & $(0.002)$ & Yes \\
Industry FE & Yes & Yes & 2 SLS \\
Estimator & OLS & OLS & 9,134 \\
Observations & 9,134 & 9,134 & 0.011 \\
R-squared & 0.046 & 0.044 & \\
\hline \hline
\end{tabular}

Notes: The dependent variable is the ratio between skilled and unskilled employment volatility. Firm-level volatility of employment is computed as the standard deviation of the estimated residual of employment growth rate on firm, sector-year fixed effects and destination-year dummies for the period 1996-2007. Export sales (imports) are measured by the logarithm of average exports (imports) of the firm during the period. Firm size is measured as the logarithm of total employment of the firm in the initial year. Firm labor productivity (average over the period) is computed on a sample of surveyed firms with more than 25 employees. Standard errors are bootstrapped in columns (1)-(2) and clustered by sector in column (3). 
Table 11 - Export sales and firms' employment volatility, skilled/unskilled. Before versus after China in the WTO.

\begin{tabular}{|c|c|c|c|c|c|c|}
\hline \multirow[t]{2}{*}{ Dep Var: } & \multicolumn{3}{|c|}{$\begin{array}{l}\text { S.D. residual employment growth } \\
\text { skilled/unskilled }\end{array}$} & \multicolumn{3}{|c|}{$\begin{array}{l}\text { S.D. residual employment growth } \\
\text { skilled/unskilled }\end{array}$} \\
\hline & $(1)$ & $(2)$ & (3) & $(4)$ & $(5)$ & $(6)$ \\
\hline Export Sales & $\begin{array}{c}-0.037^{* * *} \\
(0.009)\end{array}$ & & $\begin{array}{l}-0.021 \\
(0.018)\end{array}$ & $\begin{array}{c}-0.043 * * * \\
(0.008)\end{array}$ & & $\begin{array}{c}-0.032 * * \\
(0.015)\end{array}$ \\
\hline Export Sales (no French) & \multicolumn{3}{|c|}{$\begin{array}{c}-0.009 * * \\
(0.004)\end{array}$} & \multicolumn{3}{|c|}{$\begin{array}{l}-0.011^{* *} \\
(0.005)\end{array}$} \\
\hline Firm' size & $\begin{array}{c}0.345^{* * *} \\
(0.032)\end{array}$ & $\begin{array}{c}0.322 * * * \\
(0.024)\end{array}$ & $\begin{array}{c}0.330 * * * \\
(0.044)\end{array}$ & $\begin{array}{c}0.276^{* * *} \\
(0.037)\end{array}$ & $\begin{array}{c}0.250 * * * \\
(0.035)\end{array}$ & $\begin{array}{c}0.266 * * * \\
(0.060)\end{array}$ \\
\hline Imports & $\begin{array}{l}0.009 * * \\
(0.004)\end{array}$ & $\begin{array}{c}0.004 \\
(0.004)\end{array}$ & $\begin{array}{c}0.006 \\
(0.006)\end{array}$ & $\begin{array}{c}0.002 \\
(0.006)\end{array}$ & $\begin{array}{l}-0.004 \\
(0.005)\end{array}$ & $\begin{array}{l}-0.000 \\
(0.007)\end{array}$ \\
\hline Period & \multicolumn{3}{|c|}{ Before China WTO } & \multicolumn{3}{|c|}{ After China WTO } \\
\hline Industry FE & Yes & Yes & Yes & Yes & Yes & Yes \\
\hline Estimator & OLS & OLS & 2SLS & OLS & OLS & $2 S L S$ \\
\hline Observations & 14,933 & 14,933 & 14,933 & 15,135 & 15,135 & 15,135 \\
\hline R-squared & 0.026 & 0.025 & 0.018 & 0.011 & 0.011 & 0.005 \\
\hline
\end{tabular}

Notes: The dependent variable is the ratio between skilled and unskilled employment. Firm-level volatility of employment is computed as the standard deviation of the estimated residual of employment growth rate on firm, sector-year fixed effects and destination-year dummies for the two sub-periods 1996-2001 and 2002-2007. Export sales (imports) are measured by the logarithm of average exports (imports) of the firm over the two periods. Firm size is measured as the logarithm of total employment of the firm in the initial year. Standard errors are bootstrapped in columns (1), (2), (4) and (5) and clustered by sector in columns (3) and (6). 


\section{Conclusion}

This paper investigates how globalization shapes labor markets by assessing the impact of firms' total exports on the volatility of workers of different skill levels, and therefore on the job stability of workers of different skill levels. Relying on an econometric strategy that deals with reverse causality, our results show that exporting firms facing foreign demand shocks adjust their unskilled labor demand more than the skilled one. Firms with greater export sales, exporting more products to more destinations have a higher volatility of unskilled labor demand, relative to the volatility of skilled labor demand. This implies that unskilled workers are more affected by globalization shocks (as revealed by improved export performances of firms) than skilled workers in terms of job stability.

Our findings show that inequalities between skilled and unskilled workers associated with international trade are reinforced when looking at job stability as labor market outcome. Firms that are more engaged and diversified in export markets help to explain the stability of skilled labor jobs and the increased precariousness of unskilled jobs. These findings show that the impact of international trade on labor market inequalities should not only be thought of in static terms, referring to wages and employment, but also in dynamic terms, referring to job security. Further research would be useful to dig further into related questions. 


\section{Bibliography}

Albornoz, F., Pardo, H. F. C., Corcos, G., and Ornelas, E. (2012). Sequential exporting. Journal of International Economics, 88(1):17-31.

Arkolakis, C. (2010). Market penetration costs and the new consumers margin in international trade. Journal of Political Economy, 118(6):1151 - 1199.

Artopoulos, A., Friel, D., and Hallak, J. C. (2011). Lifting the domestic veil: The challenges of exporting differentiated goods across the development divide. Technical report.

Autor, D. H., Levy, F., and Murnane, R. J. (2003). The skill content of recent technological change: An empirical exploration. The Quarterly Journal of Economics, 118(4):12791333.

Berman, N., Berthou, A., and Hericourt, J. (2015). Export dynamics and sales at home. Journal of International Economies, 96:298-310.

Bernard, A., Jensen, J., Redding, S., and Schott, P. (2007). Firms in international trade. Journal of Economic Perspectives, 21:105-130.

Besedeš, T. and Prusa, T. J. (2006a). Ins, outs, and the duration of trade. Canadian Journal of Economics, 39(1):266-295.

Besedeš, T. and Prusa, T. J. (2006b). Product differentiation and duration of US import trade. Journal of International Economics, 70(2):339-358.

Biscourp, P. and Kramarz, F. (2007). Employment, skill structure and international trade: Firm-level evidence for france. Journal of International Economics, 72(1):22 - 51.

Brambilla, I., Lederman, D., and Porto, G. (2012). Exports, export destinations and skills. American Economic Review, 102:3406-3438.

Burstein, A. and Vogel, J. (2017). International Trade, Technology, and the Skill Premium. Journal of Political Economy, 125(5):1356-1412.

Caselli, F., Koren, M., Lisicky, M., and Tenreyro, S. (2015). Diversification through Trade. NBER Working Papers 21498, National Bureau of Economic Research, Inc.

Cavusgil, S. T. and Zou, S. (1994). Marketing strategy-performance relationship: An inves- 
tigation of the empirical link in export market ventures. Journal of Marketing, 58(1):1.

Cunat, A. and Melitz, M. (2012). Volatility, labor market flexibility, and the pattern of comparative advantage. Journal of the European Economic Association, 10(2):15424774.

Davidson, Carl, L. M. and Matusz, S. (1999). Trade and search generated unemployment. Journal of International Economics, 48(3):271-29.

di Giovanni, J. and Levchenko, A. A. (2009). Trade openness and volatility. The Review of Economics and Statistics, 91(3):558-585.

di Giovanni, J., Levchenko, A. A., and Mejean, I. (2014). Firms, destinations, and aggregate fluctuations. Econometrica, 82(4):1303-1340.

di Giovanni, J., Levchenko, A. A., and Mejean, I. (2018). The micro origins of international business-cycle comovement. American Economic Review, 108(1):82-108.

Eaton, J., Kortum, S., and Kramarz, F. (2011). An anatomy of international trade: Evidence from french firms. Econometrica, 79(5):1453-1498.

Harrigan, J. and Reshef, A. (2015). Skill-biased heterogeneous firms, trade liberalization and the skill premium. Canadian Journal of Economics, 48(3):1024-1066.

Helpman, E., Itskhoki, O., Muendler, M. A., and Redding, S. (2017). Trade and inequality: From theory to estimation. Review of Economic Studies, 84(3):357-40.

Helpman, E., Itskhoki, O., and Redding, S. (2010). Inequality and unemployment in a global economy. Econometrica, 78(3):1239-1283.

Hess, W. and Persson, M. (2011). Exploring the duration of EU imports. Review of World Economics, 147(4):665-692.

Kalemli-Ozcan, S., Sorensen, B., and Volosovych, V. (2014). Deep financial integration and volatility. Journal of the European Economic Association, 12(6):1558-1585.

Kramarz, F., Martin, J., and Mejean, I. (2017). Volatility in the small and in the large: The lack of diversification in international trade. CEPR Discussion Paper 11534.

Krebs, T., Krishna, P., and Maloney, W. (2010). Trade policy, income risk, and welfare. The 
Review of Economics and Statistics, 92(3):467-481.

Kurz, C. and Senses, M. (2016). Importing, exporting and firm-level employment volatility. Journal of International Economies, 98:160-175.

Matsuyama, K. (2007). Beyond icebergs: Towards a theory of biased globalization. Review of Economic Studies, 74:237-53.

Melitz, M. (2003). The impact of trade on intra-industry reallocations and agregate industry productivity. Econometrica, 71:1695-725.

Pissarides, C. A. (1974). Risk, job search, and income distribution. Journal of Political Economy, 82(3):1255-68.

Vannoorenberghe, G. (2012). Firm-level volatility and exports. Journal of International Economies, 86:57-67.

Verhoogen, E. (2008). Quality upgrading and wage inequality in the mexican manufacturing sector. Quarterly Journal of Economics, 123:489-530.

Yeaple, S. (2005). A simple model of firm heterogeneity, international trade, and wages. Journal of International Economics, 65:1-20. 


\section{Appendix A1. Theoretical Framework}

In this section we present a theoretical framework which delivers predictions in line with our empirical findings. We first discuss a general case where we do not assume any specific functional form for the production function. Then, we move to the CES case.

\section{A1.1 The General Case}

We present a simple theoretical framework to describe the main mechanisms through which firms' export sales may have a heterogeneous effect on the volatility of employment of different skills.

We consider a framework in which a firm serves both its domestic market and possibly foreign destinations, in which case it incurs fixed export costs. The demand addressed to the firm is stochastic in both markets. This is the only source of uncertainty considered here. Its distribution is known ex-ante but, on export markets, it depends upon the firm's investment in fixed costs of exporting in period $t, f_{t}$. This investment must be made before demand uncertainty is resolved for the period. Since higher fixed costs prop up demand by allowing the exploration of new markets and an increase in marketing investment in markets already served (Eaton et al., 2011 and Arkolakis, 2010), we assume the expected level of exports, $E\left(x_{t}\right)$, to be increasing in the level of fixed costs, $\partial E\left(x_{t}\right) / \partial f_{t}>0$. This creates a one-to-one correspondence between fixed export costs and expected export level. Once uncertainty is resolved, the firm knows the demand it faces in each market and can produce accordingly, with output equal to the sum of domestic and foreign sales: $q_{t}=d_{t}+x_{t}$.

For the sake of generality, we do not specify functional forms. We simply claim that the production function is homogeneous of degree one and uses two factors of production: skilled and unskilled labor. We take a partial equilibrium approach, and assume that the relative wage remains constant over time. Accordingly, production requires a constant unskilled-toskilled labor ratio, called $\lambda$. Since fixed costs are relatively skill-intensive, we assume they are paid in unit of skilled labor only. We indicate with $u_{t}$ the firm's unskilled labor demand. 
Therefore, its skilled labor demand can be written as: $s_{t}=\frac{u_{t}}{\lambda}+f_{t}$, where $f_{t}$ is the number of units of skilled labor needed.

We define volatility as the standard deviation of the growth rate and assume that, for a given firm's size, the volatility of its total sales is an increasing function of its expected exports, and therefore of its fixed export costs. This is in line with empirical findings in Vannoorenberghe (2012), which show that the volatility of a firm's total sales increases with the share of exports in its total sales. Since we do not consider any time trend in the variables of interest, the stochastic distribution of demand in each market is constant over time as well. Considering that unskilled labor only enters the variable cost and that the production function is homogeneous of degree one, we can state that:

Proposition 1 For a given firm size, the volatility of unskilled labor demand is an increasing function of the level of exports.

The implications are less straightforward for skilled labor, which is used not only in production, but also in fixed costs. Given the constant ex-ante distribution of demand, however, these fixed costs are also constant over time $\left(f_{t} \equiv f\right)$. The volatility of skilled labor demand thus can be expressed as follows

$$
\sigma_{i s}^{2}=\sigma_{i s}^{2}\left(\frac{s_{t}-s_{t-1}}{s_{t-1}}\right)=\sigma_{i s}^{2}\left(\frac{u_{t}-u_{t-1}}{u_{t-1}} \times \frac{u_{t-1}}{u_{t-1}+\lambda f}\right)
$$

where $\sigma_{i s}^{2}$ denotes firm i's volatility of high-skilled labor, $s$, with $\sigma_{i s}$ the standard deviation. Absent any time trend, the last term on the right hand side can be considered approximately constant so that,

$$
\sigma_{i s}^{2}=\frac{\bar{u}}{\bar{u}+\lambda f} \sigma_{i u}^{2}
$$

where $\bar{u}$ is the average firm's unskilled employment level over the period, and $\sigma_{i u}^{2}$ denotes firm i's volatility of low-skilled labor, $u$. The above equation can be rewritten as the ratio of 
the volatility of skilled labor over unskilled labor:

$$
\frac{\sigma_{i s}^{2}}{\sigma_{i u}^{2}}=\frac{\bar{u}}{\bar{u}+\lambda f}
$$

Given the one-to-one correspondence between fixed cost and expected export level, this leads to the following proposition:

Proposition 2 For a given firm size, the relative volatility of skilled labor demand (i.e., in proportion of unskilled labor demand volatility) is a decreasing function of the level of exports.

Note finally that, even for a given firm size, the impact of increased exports on the volatility of the firm's skilled labor demand is not known a priori: the increased volatility of sales tends to raise it, while the higher fixed costs reduce it. Therefore, the final effect remains an empirical question.

\section{A1.2 CES Application}

This section presents a simple partial equilibrium model to study the relationship between exports and labor volatility of employment. To distinguish the effect of exports on labor volatility across skills we use a cost structure of production where the fixed cost of entering the foreign market is paid in unit of skilled labor.

The assumption that fixed export costs are intensive in skilled labor is in line with empirical findings, and with the preliminary evidence presented in the previous section. Firms adapt their products to the standards and regulations in the destination country and to the taste of foreign consumers. This adaptation process requires services and task-inputs more skilled intensive, such as marketing research, communication with clients or intermediaries and distribution. The existence of services costs to export that are skilled intensive is in line with the model developed by Matsuyama (2007).

\section{Production}

The world consists of two countries, Home and the rest of the world, $j$. For simplicity, the following analysis considers only firms located in the Home country. There is a continuum 
of firms, each producing a differentiated variety in monopolistic competition. Production of final goods requires two different types of labor: unskilled and skilled labor, both inelastically supplied. Heterogeneous firms with different productivity levels, $\varphi$, are introduced, in keeping with Melitz (2003). We adopt a CES production technology that combines skilled and unskilled labor to produce final goods. The elasticity of substitution between the two types of labor is $\theta=\frac{1}{1-\alpha}$. We assume that skilled and unskilled labor are imperfect substitutes, hence $0<\alpha<1$ and $1 \leq \theta \leq \infty$. The production function of each firm $i$ is then:

$$
q_{i}(\varphi)=\varphi_{i}\left(s_{i}^{\alpha}+u_{i}^{\alpha}\right)^{\frac{1}{\alpha}}
$$

where $s_{i}$ and $u_{i}$ represent skilled labor and unskilled labor respectively. We assume that the fixed export costs that firms have to pay to reach each foreign destination market $j$ are paid with skilled labor. This implies that the the total production cost is:

$$
T C_{i j}(\varphi)=A C\left(\varphi_{i}\right)+w_{s} f_{i j}
$$

The price that a firm obtains for a unit of product depends on the quantity it sells and on a idiosyncratic shock, $\phi_{i j}$. We assume that $\phi_{i j}$ is drawn independently in each period from a time invariant country-specific distribution with mean zero and variance $\sigma_{i j}^{2}, \phi_{i j} \sim\left(0, \sigma_{i j}^{2}\right)$. Using a CES utility function, the demand addressed to a firm selling in market $j$ is:

$$
q_{i j}=e^{\phi_{i j}} A_{j} p_{i j}^{1-\sigma}
$$

where $\phi_{i j}$ is the stochastic shock, and $A_{j}=X_{j} P_{j}^{\sigma-1}$ is real expenditures on a variety sold in destination $j$. Firms, facing that demand with constant elasticity $\sigma$, choose the price that maximizes their profits. Prices for domestic firms are given by $p_{d}(\varphi)=\frac{\sigma}{\sigma-1} \frac{c_{i}}{\varphi}$; while prices for exporting firms vary by market $j$ depending on the variable trade cost $p_{i j}(\varphi)=p_{d}\left(\tau_{i j}\right)$. Prices reflect a constant markup $\frac{\sigma}{\sigma-1}$ over marginal cost. Equation (9) shows that firms with larger export sales have lower marginal costs (higher productivity) or/and a positive foreign 
demand shock.

In this model, marginal costs can be divided into an intrinsic productivity term $(\varphi)$ and the CES wage index $\left(c_{i}\right)$, which combines the ratio of the unskilled wage to the share parameter for unskilled labor and the skilled wage $\left(w_{u}\right)$. The CES wage index is given by $c_{i}^{\frac{\alpha}{\alpha-1}}=w_{s}^{\frac{\alpha}{\alpha-1}}+\left(\frac{w_{u}}{a_{u}}\right)^{\frac{\alpha}{\alpha-1}}$. Combining demand and price functions, export sales $\left(q_{i j} \times p_{i j}\right)$ for each firm and market are given by:

$$
x_{i j}(\varphi, \phi)=q_{i j} \times p_{i j}=e^{\phi_{i j}} A_{j}\left(\frac{\sigma}{\sigma-1} \frac{c_{i}}{\varphi} \tau_{i j}\right)^{1-\sigma}
$$

Profits from each export market are given by $\pi_{i j}(\varphi, \phi)=\frac{x_{i j}}{\sigma}-f_{i j}$. Only firms that have operating export profits to cover the fixed export cost will be able to sell their products abroad.

\section{Labor Demand}

Firms' skilled and unskilled labor demands are determined by profit maximization. Plugging the production function into the profit function and then using the goods market equilibrium equation yields the firms' skilled and unskilled labor demands for exporting firms selling in several destinations:

$$
s_{i j}\left(\varphi_{i}, \phi_{i j}\right)=\frac{q_{i j}\left(\varphi_{i}, \phi_{i j}\right)}{\varphi_{i}} c_{i j}^{\frac{1}{1-\alpha}}\left(w_{s}\right)^{\frac{1}{\alpha-1}}+f_{i j} w_{s}
$$

and

$$
u_{i j}\left(\varphi_{i}, \phi_{i j}\right)=\frac{q_{i j}\left(\varphi_{i}, \phi_{i j}\right)}{\varphi_{i}} c_{i j}^{\frac{1}{1-\alpha}}\left(w_{u}\right)^{\frac{1}{\alpha-1}}
$$

As can be noticed, firms' skilled and unskilled labor demand are affected by dynamic of the i.i.d. demand shock, $\phi_{i j}$. Notice that the subscript $j$ refers to foreign destination. However, firm level data only report the overall amount of labor. Therefore, in what follows, we first derive labor demand volatility measures per destination. Then, to be consitent with our 
empirical part, those volatility measures will be aggregate across destinations.

\section{Volatility}

We can now derive the predictions of our model for the volatility of employment across skills at the firm level. The employment volatility of firm $i$ on market $j$ is defined as the variance of the growth rate of its skilled and unskilled labor demands.

Taking first difference in logs over time of equation (11) gives the dynamics of the skilled labor demand, which is: ${ }^{24}$

$$
g_{s_{i j t}} \equiv d l n s_{i j t}=d l n q_{i j t}-d \ln \varphi_{i}+\frac{1}{1-\alpha} d l n c_{i j}+\frac{1}{\alpha-1} d l n w_{s}+d / n\left(1+\frac{f_{i j} w_{s}}{\Omega\left(\phi_{i j t}\right)}\right),
$$

where we set

$$
\Omega\left(\phi_{i j t}\right)=\frac{q_{i j t}}{\varphi_{i}} c_{i j}^{1-\alpha} W_{s}^{\frac{\alpha}{1-\alpha}}
$$

Similarly for unskilled labor demand in (11) we get:

$$
g_{u_{i j t}} \equiv d \ln u_{i j t}=d \ln q_{i j t}-d \ln \varphi_{i}+\frac{1}{1-\alpha} d \ln c_{i j}+\frac{1}{\alpha-1} d / n w_{u}
$$

Plugging equation (9) into (13) and (15), and using a Taylor approximation of equation (9), we can derive the volatility of skilled and unskilled labor demands, which write,

$$
\begin{aligned}
\operatorname{Var}\left(g_{s_{i j t}}\right) & =\operatorname{Var}\left(d \phi_{i j t}+d \ln \left(1+\frac{f_{i j}}{\Omega\left(\phi_{i j t}\right)}\right)\right) \\
& =\operatorname{Var}\left(d \phi_{i j t}\right)+\operatorname{Var}\left(d \ln \left(1+\frac{f_{i j}}{\Omega\left(\phi_{i j t}\right)}\right)\right)+2 \operatorname{cov}\left(d \phi_{i j t} ; d \ln \left(1+\frac{f_{i j}}{\Omega\left(\phi_{i j t}\right)}(1) 6\right)\right.
\end{aligned}
$$

\footnotetext{
${ }^{24} \operatorname{In}$ the $\log$ linearization we used the following approximation: $\ln (x+y)=\ln (x(1+y / x)$.
} 
and

$$
\operatorname{Var}\left(g_{u_{i j t}}\right)=\operatorname{Var}\left(d \phi_{i j t}\right)
$$

Comparative statics on (16) and (17) with respect to the stochastic shock $\phi_{i j}$ shows that the skilled intensive fixed costs makes the volatility of skilled labor demand to foreign demand shocks smaller than the volatility of unskilled labor demand:

$$
\frac{\partial \operatorname{Var}\left(g_{s_{i}}\right)}{\partial \phi_{i j}}<\frac{\partial \operatorname{Var}\left(g_{u_{i}}\right)}{\partial \phi_{i j}}
$$

The inequality in equation (18) holds because $\Omega\left(\phi_{i j t}\right)$, which enter in the denominator of equation (16), is positively related to $q_{i j t}$ and therefore to the stochastic shock $\phi_{i j}$ (see equations (14) and (9)). In our framework a firm can sell to more destinations. Therefore, aggregating over multiple destinations, we can rewrite the expressions for the variance of skilled and unskilled labor demands, which become:

$$
\begin{aligned}
\operatorname{Var}\left(g_{s_{i t}}\right) & =\operatorname{Var}\left[\sum_{j}\left(d \phi_{i j t}+d \ln \left(1+\frac{f_{i j}}{\Omega\left(\phi_{i j t}\right)}\right)\right)\right] \\
& =\operatorname{Var}\left(\sum_{j}\left(d \phi_{i j t}\right)\right)+\operatorname{Var}\left(\sum_{j}\left(d \ln \left(1+\frac{f_{i j}}{\Omega\left(\phi_{i j t}\right)}\right)\right)\right)+\operatorname{cov}
\end{aligned}
$$

and

$$
\operatorname{Var}\left(g_{u_{i t}}\right)=\operatorname{Var}\left(\sum_{j} d \phi_{i j t}\right)
$$

Notice that also with multiple destinations we can find conditions for which $\frac{\partial \operatorname{Var}\left(g_{s_{i}}\right)}{\partial \Phi_{i}}<$ $\frac{\partial \operatorname{Var}\left(g_{u_{i}}\right)}{\partial \Phi_{i}}$. Comparing equations (19) to (20), it appears that the variance of skilled remains 
larger than for unkilled workers, which is:

$$
\operatorname{Var}\left(g_{s_{i} t}\right)>\operatorname{Var}\left(g_{u_{i} t}\right)
$$

the condition in $(21)$ replicates the result for the single destination case (see equations (16) and (17)). 


\section{Appendix A2. Descriptive Statistics}

Table A1 - In-sample descriptive statistics

\begin{tabular}{lccccc}
\hline \hline & Obs & Mean & Std Dev & Min & Max \\
\hline Volatility skilled/unskilled & 17,696 & 1.95 & 1.57 & 0.002 & 46.51 \\
Volatility high skilled & 17,696 & 0.36 & 0.19 & 0.000 & 1.87 \\
Volatility low skilled & 17,696 & 0.24 & 0.14 & 0.005 & 1.22 \\
Export (In) & 17,696 & 10.51 & 3.21 & 1.427 & 20.01 \\
N. destinations (In) & 17,696 & 1.17 & 1.05 & 0.08 & 4.73 \\
N. exported products (In) & 17,696 & 1.56 & 1.39 & 0.08 & 7.54 \\
Intensive margin (In) & 17,696 & 10.23 & 1.76 & 3.93 & 17.79 \\
Import (In) & 17,696 & 8.86 & 5.46 & 0.000 & 20.17 \\
Employment (In) & 17,696 & 3.23 & 1.05 & 0.693 & 5.97 \\
\hline \hline
\end{tabular}

Table A2 - Decile of Volatility skilled/unskilled

\begin{tabular}{lccccccccc}
\hline \hline Decile: & 1 & 2 & 3 & 4 & 5 & 6 & 7 & 8 & 9 \\
\hline Volatility skilled/unskilled & 0.33 & 0.77 & 1.01 & 1.23 & 1.47 & 1.73 & 2.025 & 2.51 & 3.29 \\
\hline
\end{tabular}

Table A3 - Within/Between variance in firm employment growth

\begin{tabular}{lcc}
\hline \hline & \multicolumn{2}{c}{ Variance in employment growth } \\
\cline { 2 - 3 } & Within & Between \\
\hline Unskilled employment & 0.40 & 0.10 \\
Skilled employment & 0.45 & 0.14 \\
Unskilled hours worked & 0.31 & 0.20 \\
Skilled hours worked & 0.33 & 0.26 \\
\hline
\end{tabular}

We classify a firm as an exporter if the firm exported during at least one year during the period 1996-2007. The table reports information on number of observations, mean values, standard deviation, minimum and maximum values for: volatility of total employment, volatility of high and low-skilled labor, the ratio of labor demand volatility, the ratio of volatilities of hours worked, the logarithm of export, and of employment. The average exporting firm employs 25 workers. 


\section{Appendix A3. First Stage}

Table A4 - Export sales and firms' employment volatility, skilled/unskilled. First stage regression results.

\begin{tabular}{lccc}
\hline \hline Dep Var: & \multicolumn{3}{c}{ Export Sales } \\
\hline & $(1)$ & $(2)$ & $(3)$ \\
Sector RER & $1.131^{* * *}$ & & $0.585^{* * *}$ \\
& $(0.120)$ & & $(0.106)$ \\
Initial Export & & $0.254^{* * *}$ & $0.248^{* * *}$ \\
& & $(0.018)$ & $(0.018)$ \\
Firm' size & $0.928^{* * *}$ & $0.536^{* * *}$ & $0.545^{* * *}$ \\
& $(0.064)$ & $(0.047)$ & $(0.045)$ \\
Imports & $0.252^{* * *}$ & $0.173^{* * *}$ & $0.167^{* * *}$ \\
& $(0.013)$ & $(0.008)$ & $(0.008)$ \\
\hline Industry FE & Yes & Yes & Yes \\
\hline F-stat & 88 & 189 & 103 \\
Sargan Test & & & 0.557 \\
Observations & 17694 & 17694 & 17694 \\
\hline \hline
\end{tabular}

Notes: Export sales does not include the export value in initial year (as it is used as IV). It is measured by the logarithm of average exports of the firm during the period. Standard errors are clustered by sector in columns. 


\section{Appendix A4. Robustness Checks}

In the following tables we perform additional robustness checks.

Table A5 - Export sales and firms' employment volatility, skilled/unskilled. Robustness check using alternative definition of skills.

\begin{tabular}{lccc}
\hline \hline Dep Var: & \multicolumn{3}{c}{$\begin{array}{c}\text { S.D. residual employment } \\
\text { growth, non-production/production }\end{array}$} \\
\hline Export Sales & $(1)$ & $(2)$ & $(3)$ \\
& $-0.031^{* * *}$ & & $-0.037^{* * *}$ \\
Export Sales (no French) & $(0.004)$ & & $(0.008)$ \\
& & $-0.012^{* * *}$ & \\
Firm' size & & $(0.003)$ & $0.263^{* * *}$ \\
& $0.257^{* * *}$ & $0.244^{* * *}$ & $(0.037)$ \\
Imports & $(0.018)$ & $(0.019)$ & -0.001 \\
& -0.003 & $-0.006^{* * *}$ & $(0.004)$ \\
\hline Industry FE & $(0.003)$ & $(0.002)$ & Yes \\
Estimator & Yes & Yes & $2 S \mathrm{SS}$ \\
\hline IV: RER & OLS & OLS & $0.586^{* * *}$ \\
& & & $(0.103)$ \\
IV: Export (t=0) & & & $0.247^{* * *}$ \\
& & & $(0.018)$ \\
\hline Observations & 17,763 & 17,763 & 17,763 \\
R-squared & 0.046 & 0.045 & 0.023 \\
F-stat first Stage & & & 102 \\
Sargan Test & & & 0.356 \\
\hline \hline
\end{tabular}

Notes: The dependent variable is the ratio between non-production and production workers volatility. Firm-level volatility of employment is computed as the standard deviation of the estimated residual of employment growth rate on firm, sector-year fixed effects and destination-year dummies for the period 1996-2007. Export sales (imports) are measured by the logarithm of average exports (import) of the firm during the period. Firm size is measured as the logarithm of total employment of the firm in the initial year. Standard errors are bootstrapped in columns (1) and (2) and clustered by sector in column (3). 
Table A6 - Export sales and firms' employment volatility, skilled/unskilled. Robustness check using coefficient of variation.

\begin{tabular}{|c|c|c|c|}
\hline \multirow[t]{2}{*}{ Dep Var: } & \multicolumn{3}{|c|}{$\begin{array}{l}\text { Coeff. Variation residual employment } \\
\text { growth, skilled/unskilled }\end{array}$} \\
\hline & $(1)$ & (2) & (3) \\
\hline Export Sales & $\begin{array}{c}-0.036 * * * \\
(0.006)\end{array}$ & & $\begin{array}{l}-0.032 * \\
(0.017)\end{array}$ \\
\hline Export Sales (no French) & & $\begin{array}{c}-0.017^{* * *} \\
(0.004)\end{array}$ & \\
\hline Firm' size & $\begin{array}{l}-0.004 \\
(0.017)\end{array}$ & $\begin{array}{l}-0.015 \\
(0.018)\end{array}$ & $\begin{array}{l}-0.008 \\
(0.037)\end{array}$ \\
\hline Imports & $\begin{array}{c}-0.022 * * * \\
(0.004)\end{array}$ & $\begin{array}{l}-0.025^{* * *} \\
(0.005)\end{array}$ & $\begin{array}{c}-0.023 * * * \\
(0.007)\end{array}$ \\
\hline Industry FE & Yes & Yes & Yes \\
\hline Estimator & OLS & OLS & 2SLS \\
\hline IV: RER & & & $\begin{array}{c}0.589 * * * \\
(0.103)\end{array}$ \\
\hline IV: Export $(\mathrm{t}=0)$ & & & $\begin{array}{c}0.247^{* * *} \\
(0.017)\end{array}$ \\
\hline Observations & 17,911 & 17,911 & 17,911 \\
\hline R-squared & 0.035 & 0.034 & 0.011 \\
\hline F-stat first Stage & & & 105 \\
\hline Sargan Test & & & 0.242 \\
\hline
\end{tabular}

Notes: The dependent variable is the ratio between skilled and unskilled employment volatility. Firm-level volatility of employment is computed as the coefficient of variation of the estimated residual of employment growth rate on firm, sector-year fixed effects and destination-year dummies for the period 1996-2007. Export sales (imports) are measured by the logarithm of average exports (import) of the firm during the period. Firm size is measured as the logarithm of total employment of the firm in the initial year. Standard errors are bootstrapped in columns (1) and (2) and clustered by sector in column (3). 
Table A7 - Export sales and firms' employment volatility, skilled/unskilled. Robustness check with unbalanced panel data.

\begin{tabular}{|c|c|c|c|c|}
\hline \multirow[t]{2}{*}{ Dep Var: } & \multicolumn{2}{|c|}{ S.D. residual employment growth } & \multicolumn{2}{|c|}{ S.D. residual hours worked growth } \\
\hline & $(1)$ & $(2)$ & (3) & $(4)$ \\
\hline Export Sales & $\begin{array}{c}-0.040 * * * \\
(0.013)\end{array}$ & & $\begin{array}{c}-0.031 \\
(0.018)\end{array}$ & \\
\hline Export Sales (no French) & & $\begin{array}{c}-0.018 * * * \\
(0.006)\end{array}$ & & $\begin{array}{c}-0.026 * * \\
(0.012)\end{array}$ \\
\hline Firm' size & $\begin{array}{c}0,328 * * * \\
(0.031)\end{array}$ & $\begin{array}{c}0.315^{* * *} \\
(0.031)\end{array}$ & $\begin{array}{c}0.149 * * \\
(0.061)\end{array}$ & $\begin{array}{c}0.153 * * \\
(0.057)\end{array}$ \\
\hline Imports & $\begin{array}{c}-0,002 \\
(0.031)\end{array}$ & $\begin{array}{c}-0.006^{*} \\
(0.003)\end{array}$ & $\begin{array}{l}-0.002 \\
(0.008)\end{array}$ & $\begin{array}{c}0.000 \\
(0.057)\end{array}$ \\
\hline Industry FE & Yes & Yes & Yes & Yes \\
\hline Estimator & OLS & OLS & OLS & OLS \\
\hline Observations & 28943 & 28943 & 28943 & 28943 \\
\hline R-squared & 0.007 & 0.007 & 0.001 & 0.001 \\
\hline
\end{tabular}

Notes: This able reports a robustness check using all exporting firms, even those with employment data for only two years (unbalanced data). The dependent variable is the ratio between skilled and unskilled employment or hours worked volatility. Firmlevel volatility of employment or hours worked is computed as the standard deviation of the estimated residual of employment growth rate on firm, sector-year fixed effects, firm's labor productivity and destination dummies for the period 1996-2007. Export sales are measured by the logarithm of average exports of the firm during the period. Firm size is measured as the logarithm of total employment of the firm in the initial year. Standard errors are bootstrapped in all columns.

Table A8 - Export sales and firms' employment volatility, skilled/unskilled. Robustness check including domestic firms. OLS estimations

\begin{tabular}{|c|c|c|c|c|}
\hline \multirow[t]{2}{*}{ Dep Var: } & \multicolumn{2}{|c|}{ S.D. residual employment growth } & \multicolumn{2}{|c|}{$\begin{array}{l}\text { S.D. residual hours worked } \\
\text { growth }\end{array}$} \\
\hline & (1) & (2) & (3) & (4) \\
\hline Export Sales & $\begin{array}{c}-0.042 * * * \\
(0.005)\end{array}$ & $\begin{array}{c}-0.048 * * * \\
(0.007)\end{array}$ & $\begin{array}{c}-0.040 * * \\
(0.019)\end{array}$ & $\begin{array}{c}-0.050 * * * \\
(0.019)\end{array}$ \\
\hline Export Status (dummy) & $\begin{array}{c}0.404 * * * \\
(0.054)\end{array}$ & & $\begin{array}{c}0.347 \\
(0.274)\end{array}$ & \\
\hline Churning Exporter (dummy) & & $\begin{array}{c}0.449 * * * \\
(0.081)\end{array}$ & & $\begin{array}{c}0.419 \\
(0.260)\end{array}$ \\
\hline Continuous Exporter (dummy) & & $\begin{array}{c}0.508^{* * *} \\
(0.099)\end{array}$ & & $\begin{array}{l}0.508^{*} \\
(0.293)\end{array}$ \\
\hline Firm' size & $\begin{array}{c}0.397 * * * \\
(0.022)\end{array}$ & $\begin{array}{c}0.397^{* * *} \\
(0.031)\end{array}$ & $\begin{array}{c}0.209 * * * \\
(0.057)\end{array}$ & $\begin{array}{c}0.209 * * * \\
(0.057)\end{array}$ \\
\hline Imports & $\begin{array}{c}0.002 \\
(0.002)\end{array}$ & $\begin{array}{c}0.002 \\
(0.002)\end{array}$ & $\begin{array}{l}-0.012^{*} \\
(0.006)\end{array}$ & $\begin{array}{l}-0.012^{*} \\
(0.006)\end{array}$ \\
\hline Industry FE & Yes & Yes & Yes & Yes \\
\hline Estimator & OLS & OLS & OLS & OLS \\
\hline Observations & 30862 & 30862 & 18112 & 18112 \\
\hline R-squared & 0.024 & 0.024 & 0.019 & 0.019 \\
\hline
\end{tabular}

Notes: This table reports a robustness check using all firms, domestic and exporters. The dependent variable is the ratio between skilled and unskilled employment volatility. Firm-level volatility of employment is computed as the standard deviation of the estimated residual of employment growth rate on firm, sector-year fixed effects, firm's labor productivity and destination dummies for the period 1996-2007. Export sales are measured by the logarithm of average exports of the firm during the period. Firm size is measured as the logarithm of total employment of the firm in the initial year. Standard errors are bootstrapped in all columns. 